\title{
La construcción de los censos de población del Nuevo Reino de Granada a finales del siglo XVIII
}

Sergio Paolo Solano D. Universidad de Cartagena ssolanod@unicartagena.edu.co

Recibido: marzo de 2014

Aprobado: noviembre de 2014

Resumen: Este artículo analiza cómo se construyeron los padrones de población en el Nuevo Reino de Granada de finales del siglo XVIII. Presta atención al contexto administrativo de donde emanaron las órdenes, las intenciones e intereses que motivaron la contabilización de las poblaciones, los problemas enfrentados, las soluciones asumidas y las formas cómo se clasificaron a los habitantes. Contrasta los diversos padrones realizados con base en la orden real de 1776, para mostrar las variaciones que se operaron en las formas de recoger la información. Muestra los diversos niveles de presentación de sus resultados y cómo los resúmenes obedecieron a la influencia de un pensamiento ilustrado que no necesariamente guardaba correspondencia automática con la realidad.

Palabras claves: censos de población, Nuevo Reino de Granada, colonias, siglo XVIII, recolección de información, presentación de resultados.

\section{The construction of the censuses of population of the New King of Granada at the end of the 18th-century}

Abstract: This article discusses how the registers of late 18th-century New Kingdom of Granada population in the colonies was built. Pay attention to the administrative context from which emanated orders, intentions and interests that motivated posting of populations, faced problems, assumed solutions and shapes how classified inhabitants. It contrasts the various rolls made with base in the Royal order of 1776 , to show variations that are operated in the ways of collecting the information. It shows the different levels of presentation of their results and how the summaries

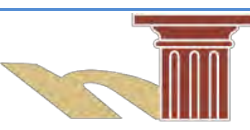

EL TALLER DE LA HISTORIA, vol. 7, n. ${ }^{\circ}$ 7, 2015, págs. 41- 99. Issn: 1657-3633; e-Issn: 2382-4794. Programa de Historia, Facultad de Ciencias Humanas, Universidad de Cartagena de Indias, Colombia
} 
were due to the influence of a pictorial thought not necessarily keeping automatic correspondence with reality.

Key words: Census of population, Latin America, colonies, 18th-century, collection of information, presentation of results.

\section{Presentación}

En este artículo estudiamos los motivos que llevaron a realizar los padrones de población en el Nuevo Reino de Granada a finales del siglo XVIII, como también los procedimientos que se emplearon para recoger la información, cómo se aplicaban las categorías socio-raciales a las personas, el papel de los empadronadores en la recopilación de los datos, las relaciones entre estos y los empadronados al momento de determinar en qué categoría quedaban adscritos estos últimos, y los mecanismos a los que se acudía para resolver las dudas.

También estudiamos las formas como se presentaron los resultados de esos padrones: los que registraron datos discriminados sobre libres y esclavos, la condición socio-racial de los habitantes, edades, ocupaciones y estado civil de la población; los que no hicieron referencia alguna a las condiciones socio-raciales de los habitantes; las razones que llevaron a elaborar los resúmenes generales de las provincias y de sus distintos partidos, en los que los datos aparecen agregados en las categorías de "eclesiásticos, blancos, indios, libres de todos los colores y esclavos de varios colores". Y por último la elaboración el resumen general para todo el virreinato, el que se ensambló con base en los resúmenes provinciales de los años de 1778 a 1780, y tomando como matriz los del primer año, para el que se contó con el mayor volumen de información de las provincias.

Como puede imaginar el lector, esos aspectos remiten al estudio de las relaciones entre el orden social existente a finales del siglo XVIII, las representaciones sociales construidas por el discurso ilustrado y sus formas de expresión y de presentación. El análisis de estas relaciones implica abordar cuatro aspectos diferenciados y a la vez complementarios. El primero es el papel de las instituciones, de los discursos oficiales y de la escritura en la producción del orden social. El segundo son los procesos de construcción de los documentos que crean, reafirman o modifican las representaciones sociales. El tercero se refiere a la necesidad de contrastar esas construcciones discursivas con las prácticas sociales de las gentes en sus vidas cotidianas. Y el cuarto exige establecer qué sobrevivía de las anteriores formas de

Dossier: Cuestionando las fuentes de archivos: padrones de población, familias y sociedades coloniales en Iberoamérica, ss. XVIII-XIX 
representación social, su presencia en los documentos, y hasta dónde pueden sesgar la observación del historiador y llevarlo, tanto a desconocer las nuevas realidades que estaban emergiendo como a creer que estas automáticamente borraban viejas clasificaciones. También cruzamos los datos contenidos en los padrones de esos años para poder analizar tanto las continuidades como las transformaciones que se operaron en los sistemas de clasificación de los distintos sectores sociales de la población, y las relaciones entre esos sistemas y la jerarquía social.

Para desarrollar esta agenda es necesario tener en cuenta tres advertencias previas. Una se refiere a que la historiografía contemporánea ha demostrado que la diversidad de categorías socio-raciales era una expresión de los avances de los distintos mestizajes, y de la pérdida de fronteras entre algunas de las clasificaciones socio-raciales. Otra es que en la posición y las posibilidades de cambio de status social de las personas y de las familias, además del color de la piel y el fenotipo, también intervinieron otros factores. Y la otra, usualmente olvidada por la historiografía es que para finales del periodo colonial viejas y nuevas categorías socioraciales y políticas se sobrepusieron, y aunque desde la crisis de 1808 en adelante las acciones políticas de los actores sociales fueron las que empezaron a marcar el derrotero, en otros escenarios, en especial en la vida cotidiana, continuaron operando muchos aspectos de las formas "tradicionales" de leer los lugares de las personas y familias en el orden socio-racial. Eso explica, dicho sea de paso que bajo la República era fácil que se desarrollaran unas lecturas racializadas de la sociedad y de sus distintos sectores.

El artículo está ordenado en cuatro apartes. En el primero estudiamos las formas como se organizó el censo de 1777 en la Nueva Granada. En el segundo analizamos las categorías socio-raciales que aparecen en los censos de ese año de algunas localidades del mundo andino y de las provincias de Cartagena y Riohacha. En el tercero contrastamos esas categorías y las que aparecen en los resúmenes de los censos de ese año. Y en el cuarto aparte estudiamos lo que sucedió con esas categorías en los censos posteriores a la del año señalado.

\section{Las vicisitudes de una política unitaria para contabilizar a los habitantes del imperio}

En diferentes años de la segunda mitad del siglo XVIII la corona española ordenó contabilizar a la población de la metrópoli. En 1768 en España se realizó el censo del Conde de Aranda, y en 1787 y 1797 se realizaron los censos del conde de Floridablanca y el del ministro Godoy respectivamente. Durante el último cuarto de ese

Dossier: Cuestionando las fuentes de archivos: padrones de población, familias y sociedades coloniales en Iberoamérica, ss. XVIII-XIX 
siglo esas iniciativas se replicaron en los dominios españoles en América y Filipinas, realizándose varios censos con base en una orden real emitida el 10 de noviembre de 1776, la que decretó contabilizar a los habitantes de las colonias "con la debida distinción de estados, clases y castas, de todas las personas de ambos sexos, sin excluir a los párvulos". ${ }^{1}$

Se trató de una política unitaria que buscaba tres propósitos: el más elemental era satisfacer la necesidad del pensamiento ilustrado por conocer y en la medida de lo posible cuantificar las realidades natural y social. El otro objetivo era superar el desconocimiento que tenían las autoridades metropolitanas sobre las colonias, ${ }^{2} \mathrm{y}$ que la imagen de conjunto de toda la población del imperio español sirviera para que la corona y sus funcionarios tuvieran las herramientas necesarias para el buen gobierno y la defensa del imperio. De igual forma esos saberes también eran imprescindibles para impulsar la iniciativa privada, para intentar desvertebrar viejos privilegios, y para ampliar la esfera de influencia del Estado. ${ }^{3}$

Los principales obstáculos a enfrentar eran las diferencias de las sociedades a empadronar, ${ }^{4}$ como también las distintas experiencias de empadronamientos entre la metrópoli y las colonias. Por ejemplo, el censo del conde Aranda ordenado con la intención de facilitar la gestión administrativa de la monarquía se realizó con base en un formulario único que debían llenar los curas de cada parroquias, y luego los obispos debían hacer un resumen sobre su jurisdicción eclesiástica. La unidad de registro no era el vecino sino el habitante, y conminó a las autoridades ordinarias y eclesiásticas a levantarlo sin anotar los nombres de los empadronados, con el propósito de no generar las usuales desconfianzas. Se suprimieron las inscripciones de las categorías sociales y se le dio énfasis a las ocupaciones, lo que permitió contabilizar a sectores de la población que antes se excluían porque no entraban en los

\footnotetext{
${ }_{1}^{1}$ Archivo General de la Nación-Colombia, Sección Colonia, fondo Censos Redimibles-Censos Varios Departamentos (en adelante AGN, SC, CR-CVD), leg.8, ff.224r.-v.

2 Juan Marchena, “'Su Majestad quiere saber' Información oficial y reformismo borbónico: el mundo andino bajo la mirada de la Ilustración", en Procesos n. ${ }^{\circ 22}$, Quito, Universidad Andina Simón Bolívar, 2005, pp.45-83.

${ }^{3}$ Ver la carta de 1790 del virrey del Perú Francisco Gil y Lemos, demandando información a los intendentes. Archivo General de Indias (AGI), Lima, leg.691, exp.17; también ver la carta de 1796 del virrey O’Higgins, de ese virreinato a los mismos funcionarios. AGI, Lima, leg.714, exp.57.

${ }^{4}$ Los términos de estratificación de la sociedad española eran mucho más homogéneos que las coloniales. Aquella no contaba con la diversidad socio-racial tan compleja y se clasificaba por estamentos en nobles, clero y estado llano. Manuel Fernández, España y los españoles en los tiempos modernos, Salamanca, Universidad de Salamanca, 1979, pp.53-78; Magnus Mörner, La mezcla de razas en la historia de América Latina, Buenos Aires, Paidós, 1969, pp.67-72.
}

Dossier: Cuestionando las fuentes de archivos: padrones de población, familias y sociedades coloniales en Iberoamérica, ss. XVIII-XIX 
propósitos específicos de los empadronamientos fiscales o militares. ${ }^{5} \mathrm{El}$ censo del conde de Floridablanca profundizó los criterios de universalidad y homogeneidad. ${ }^{6}$

Las novedades españolas en las formas de contabilizar a los habitantes -que contrastaban con lo que hasta ese momento se había hecho en las colonias-, eran conocidas por los ilustrados que gobernaban los distintos virreinatos, capitanías e intendencias iberoamericanas. En el mismo año de su realización (1787) los resultados del censo de Floridablanca se publicaron en un libro el que debió circular entre las autoridades más altas de las colonias. Los resúmenes generales de los censos de Lima y de Ciudad de México de 1790 fueron presentados a la Corona siguiendo el patrón del resumen del censo de Floridablanca. Manuel de Guirior, virrey del Perú anotó: "Acompaño el estado de población de esta capital, conforme en cuanto se ha podido con los de la Metrópoli, por haberme parecido útil la uniformidad en esta parte material". ${ }^{7}$ Otro tanto hizo el virrey Revillagigedo con el resumen del censo de Ciudad de México: "A ejemplo del ejecutado en esa península en el de 1787, paso a manos de Vuestra Excelencia el estado general de la población de esta capital $[\ldots] ” .8$

Pero otra situación estaba representada en los curas y en los funcionarios coloniales de menor rango que estaban al frente de las provincias, partidos, ciudades, villas y parroquias, quienes solo contaban con las experiencias de las matrículas de feligresías, ${ }^{9}$ de los repartimientos de indios, de las visitas a la tierra para tasar tri-

5 Censo de Aranda, tomo I, Madrid, Real Academia de la Historia/Instituto Nacional de Estadística,
1991, p.13. (Edición facsimilar). http:// www.ine.es/ prodyser/ pubweb/ censo_aranda/ tomo1.pdf.
${ }^{6}$ Censo español executado de Orden del Rey, comunicada por el Excelentísimo Señor Conde de
Floridablanca, Primer Secretario del Estado y del Despacho, en el año de 1787, Madrid, Imprenta
Real, 1787. http:// bibliotecadigital.jcyl.es/i18n/ catalogo_imagenes/grupo.cmd?path=10074515. Para un
mayor desarrollo de estas ideas ver: Juan Hernández, "La realización del censo de Floridablanca en
el corregimiento de Murcia", en Studia Histórica: Historia Moderna n. ${ }^{\circ}$ 5, Salamanca, Universidad
de Salamanca, 1987, pp.285-297; Vicente Pérez, "La estadística demográfica en el gobierno de la
España ilustrada: recuerdo y elogio del Censo de Floridablanca", en Índice n. ${ }^{\circ} 43$, Madrid, Instituto
Nacional de Estadística/ Universidad Autónoma de Madrid, 2010, pp. $8-17$. Las diferencias entre los
censos españoles anteriores al del Conde Aranda y los posteriores han sido expuestas por Eduardo
García, "Censos de población españoles", en Estadística Española n. ${ }^{\circ} 128$, Madrid, Instituto Nacio-
nal de Estadística, 1991, pp.445-446.

${ }^{7}$ AGI, Lima, leg.700, exp.11, f.5r.

${ }^{8}$ AGI, Estado, leg.20, exp.63, f.1r.; Hugo Castro, Primer censo de Nueva España. Censo de Revillagigedo "un censo condenado", México D. F., Sociedad Mexicana de Geografía y Estadística/ Instituto Nacional de Geografía y Estadística, 2010, p.299.

${ }_{9}$ Alejandra Araya, "La Matrícula de Alday (1777-1778): imaginarios sociales y políticos en el siglo XVIII americano", en Grupo de Estudio de Historia de las Ciencias (eds.), Control social y objetivación: escrituras y tránsitos de las ciencias en Chile, Santiago de Chile, Universidad de Chile, 2012,

Dossier: Cuestionando las fuentes de archivos: padrones de población, familias y sociedades coloniales en Iberoamérica, ss. XVIII-XIX 
butos de indios, ${ }^{10}$ y censos con fines impositivos y de reclutamiento miliciano y militar. Según J uan Marchena la mayoría del tren administrativo colonial de finales del XVIII que afrontaba las demandas de información concisa y precisa por parte de las autoridades de Madrid, solo tenía a la mano las viejas experiencias del periodo de los Habsburgos, las que se caracterizaban por las informaciones engorrosas y puntillosas. ${ }^{11}$ Como al fin y al cabo este era el personal que se ponía al frente de la realización de los censos, se requería intentar homogenizar hasta donde se pudiera algunos criterios para recoger la información y presentar los resultados. En consecuencia, el que se pudiera satisfacer las expectativas de la corona iba a depender de que esas experiencias locales quedaran supeditadas a lo que se había ganado en la metrópoli con la realización de los mencionados censos.

Por parte del pensamiento ilustrado la solución de esas diferencias debía expresarse en el reforzamiento de ciertas uniformidades, en especial en lo que tenía que ver con los registros de las calidades socio-raciales de los habitantes de las colonias. No se trataba de algo novedoso pues en los intercambios de información entre altos funcionarios coloniales y los de la metrópoli cuando se hacían las alusiones a las condiciones socio-raciales de las personas siempre se utilizaban expresiones genéricas que dejaban de lado muchas particularidades que funcionaban en Hispanoamérica y las Filipinas. Más adelante volveremos sobre este aspecto de mucho interés. Por ahora solo digamos que la búsqueda de cierta homogeneidad entre los censos de población del imperio incidió de manera ostensible en la forma como se registraron a los diversos sectores de la sociedad. De ahí que cuando los censos se estudian de conjunto se observa las transformaciones que se operaron con relación a los padrones que les precedieron, como también una tendencia a su continua modernización expresada en una creciente universalidad y abstracción en las formas de recoger y de presentar los resultados, dejando de lado la gran cantidad de especificaciones de las distintas condiciones de los habitantes. ${ }^{12}$

\section{pp.15-33.}

10 Julián Ruiz, Fuentes para la demografía histórica de Nueva Granada, Sevilla, Escuela de Estudios Hispano Americanos, 1972; Los indios de Cartagena bajo la administración española en el siglo XVII, Bogotá, Archivo General de la Nación, 1996.

11 J. Marchena, “'Su Majestad quiere saber' Información oficial y reformismo borbónico: el mundo andino bajo la mirada de la Ilustración”, p.54.

12 La falta de una mirada de conjunto a los censos de población dentro del imperio español ha llevado a que algunos historiadores consideren que clasificaciones genéricas como "libres de todos los colores" obedecían a las transformaciones que se habían operado en las sociedades coloniales, en especial a la pérdida de preeminencia del factor socio-racial como determinante de la estratificación social, al protagonismo alcanzado por la condición de clase determinada por aspectos económicos, y al fortalecimiento de la condición política del vecino. Sobre estos argumentos he hecho algunos

Dossier: Cuestionando las fuentes de archivos: padrones de población, familias y sociedades coloniales en Iberoamérica, ss. XVIII-XIX 
En obediencia de la real orden de 10 de noviembre de 1776 el primer censo que se celebró en el Nuevo Reino de Granada y en otras colonias fue el de 1777. En abril de ese año el virrey Manuel Antonio Flórez ordenó levantar el padrón. ${ }^{13}$ Casi que al mismo tiempo Manuel de Guirior, virrey de Perú, emitió parecida disposición dirigida a los obispos para que movilizaran a los curas para la realización del padrón..$^{14}$ En mayo el virrey Bucareli de Nueva España hacía lo mismo con la jerarquía de la iglesia. Una vez recibida las órdenes por los intendentes (donde esta jurisdicción existía) y los gobernadores de provincias, estos notificaron a las autoridades de los partidos, corregidores, cabildos, alcaldes, a los alcaldes pedáneos y de barrios (estos últimos en ciudades y villas grandes) y a otros funcionarios locales menores, mientras que las autoridades centrales de la iglesia procedieron de igual forma con los sacerdotes. ${ }^{15}$ Ya a finales de noviembre de 1776 el Marqués de la Torre, gobernador de la isla de Cuba había ordenado llevar a cabo el padrón y en enero del año siguiente lo remitió a la Corona. ${ }^{16}$

Las autoridades centrales de Madrid no especificaron los detalles sobre cómo debían desarrollarse los padrones y presentarse los resultados. Esta falta de orientaciones precisas llevó a que en algunos casos la realización del padrón de 1777 se desarrollara echando mano de la experiencia que se había acopiado en cada virreinato. Por eso, como lo veremos más adelante, con base en la experiencia del padrón de 1777 las autoridades de los virreinatos rápidamente se percataron que debían dar orientaciones más precisas si se quería satisfacer las expectativas de Madrid. Los censos de España del Conde de Aranda (1768) y del Conde de Floridablanca (1787) dieron algunas claves para contabilizar a los habitantes de las poblaciones del imperio de acuerdo con las perspectivas del pensamiento ilustrado.

Con el acopio de experiencias durante el último cuarto de ese siglo las justificaciones de los censos se fueron perfeccionando. A comienzos de $1791 \mathrm{el}$ Conde de

comentarios en "Padrones de población, configuración socio-racial e historiografía hispanoamericana, siglo XVII", en El Taller de la Historia vol.5, n. ${ }^{\circ}$, Cartagena, Universidad de Cartagena, 2013, pp.125-178.

13 AGN, SC, CR-CVD, leg.8, f.224r.

14 AGI, Lima, leg.655, exp.78, ff.1r.-2v.

15 Archivo Histórico del Arzobispado de México, Fondo Episcopal, Secretaría Arzobispal, fondo Padrones, caja 9 cl, libro 6, i a. Citado en Ernest Sánchez, Padrón del arzobispado de México 1777, México D. F., Archivo General de la Nación, 2003, pp.69-70.

16 AGI, Indiferente General, 1527, f.10v. Agradezco al colega J avier Laviña (Universidad de Barcelona) el envío de los resúmenes de este padrón de Cuba.

Dossier: Cuestionando las fuentes de archivos: padrones de población, familias y sociedades coloniales en Iberoamérica, ss. XVIII-XIX 
Revillagigedo, virrey de Nueva España expuso a los intendentes cuales eran los propósitos del censo:

1. El medio de saber la población de los Estados o Monarquías, es formar Padrones generales de los Pueblos. De su exactitud, expresión y claridad puede fácilmente deducirse el número de personas dedicadas al estado Eclesiástico sus allegados y sirvientes, los que del secular componen ambos sexos, las que corresponden a cada clase y casta y en suma cuantos forman la población de una Intendencia cuya reunión a un solo Estado hace visible el todo y puede influir mucho para reformar o fomentar el de la constitución de los Reinos. ${ }^{17}$

También se fueron modificando las formas de empadronamiento y de presentación de los resultados a las autoridades centrales de los virreinatos y del imperio. Por ejemplo, el censo de 1777 de Nueva España (también conocido como de Bucareli, apellido del virrey que lo organizó) produjo un cuadro resumen para todo el arzobispado, gracias a que desde la administración central de ese virreinato se organizaron formularios y un equipo de trabajo dirigido por el propio virrey para recoger las informaciones y tabularlas. ${ }^{18}$ En la Nueva Granada no se procedió de igual manera y la diversidad de formas aplicadas por los empadronadores en la recolección de la información hizo que el censo de ese año fracasara. No se organizó de la forma que las autoridades ilustradas esperaban que se recogiera y se presentara la información, y cuando empezaron a llegar los padrones de las poblaciones y de los barrios de las ciudades y villas fue que se impartieron órdenes por parte de las autoridades centrales de este virreinato para demandar los resultados que esperaban. ${ }^{19}$ Solo en 1780 fue que se realizó el ensamble de un primer cuadro resumen basado en los padrones parciales recogidos de 1778 en adelante. ${ }^{20}$ Estos resúmenes se han convertido en la fuente de cifras y datos más conocido por los historiadores que estudian la sociedad del último cuarto del siglo XVIII.

17 Archivo Histórico de Veracruz, México, Instructivo, vol.1790. Citado en H. Castro, Primer censo de Nueva España. Censo de Revillagigedo "un censo condenado”, p.77.

18 AGI, Mapas y Planos, Varios, 38.

19 AGN, SC, CR-CVD, leg.8, ff.223r.-246v.; AGN, SC, fondo Virreyes, leg.2, ff.188v., 285r.-v., 292r., 299v.-301r.

20 El equipo coordinado por Hermes Tovar Pinzón reunió de forma pormenorizada y depurada cifras sobre los distintos censos del Nuevo Reino de Granada y la República de Colombia, comprendidos entre 1777 y 1830, compilación estadística construida y organizada con base en los distintos resúmenes de los censos provinciales. Hermes Tovar, Camilo Tovar y J orge Tovar, Convocatoria al poder del número. Censos y estadísticas de la Nueva Granada (1750-1830), Bogotá, Archivo General de la Nación, 1995.

Dossier: Cuestionando las fuentes de archivos: padrones de población, familias y sociedades coloniales en Iberoamérica, ss. XVIII-XIX 


\section{Las dificultades iniciales: el padrón de 1777}

Como ya anotamos hasta 1777 las únicas experiencias de contabilización de poblaciones se circunscribían a las que la iglesia periódicamente realizaba matrículas de las feligresías de las parroquias, y en determinadas circunstancias de peligro las autoridades ordinarias y militares censaban a la población masculina en condiciones de tomar las armas. ${ }^{21}$ La iglesia había cumplido un destacado papel en los periódicos conteos de la población a través de las matrículas de feligresías, como en la genealogía de las clasificaciones socio-raciales de los habitantes, tanto porque era función de los sacerdotes llevar registros de sus feligresías, como porque por ordenanza real de $1573^{22}$ los libros de bautismos, matrimonios y defunciones debían clasificarse por castas. ${ }^{23}$ Los padrones eclesiásticos se elaboraban teniendo como fundamento la idea de que la familia era el núcleo básico de la sociedad. De ahí que esa forma de contabilizar al pater familie de naturaleza eclesiástica se deslizaba en los padrones de las autoridades civiles. Se creó entonces una tradición de matricular feligresías de parroquias de acuerdo a los criterios de vecino cabeza de familia, los dependientes de aquel (esposa, hijos y agregados), el total de las "almas de confesión" (feligresía), esclavos y "estado civil", como se puede ver en las relaciones resultado de las visitas de los sacerdotes a sus parroquias. ${ }^{24}$ Por ejemplo, las matrí-

21 Un buen ejemplo de un censo con fines de defensa militar es Numeración general de todas las personas de ambos sexos, edades y calidades que se ha hecho en esta ciudad de Lima, año de 1700,2 tomos, 360 folios. Puede consultarse los originales en formato digital en Biblioteca Digital Hispánica de la Biblioteca Nacional de España, http://bdh-rd.bne.es/viewer.vm?id=0000042087\&page=1

22 La ordenanza de 1573 dirigida a la iglesia puede verse en Francisco de Solano (ed.), Cuestionarios para la formación de las relaciones geográficas de Indias. Siglos XVI-XIX, Madrid, Consejo Superior de Investigaciones Científicas, 1988, pp.16-17.

23 En libros parroquiales de Turbaco (pueblo de indios situados en las goteras de Cartagena de Indias) correspondientes a los años de 1780-1814, a las personas se les anotaron las condiciones de blancos, libres (no especifican ninguna otra condición), indios, pardos, morenos, mestizos, negros, mulatos y esclavos. AGN, SC, Libro de bautizos de Turbaco y Cartagena, rollo único, ff.230r-263r.; 75r.-189r.; 31r.-180v. Y los pocos libros supérstites de bautismos y matrimonios de las iglesias de Cartagena del tránsito entre los siglos XVIII y XIX, están organizados en libros de "pardos" y de "blancos", incluyendo los primeros a los "morenos" (negros libres) y esclavos, al igual que los de Santa Marta. Ildefonso Gutiérrez, "Los libros de registro de pardos y morenos en los archivos parroquiales de Cartagena de Indias", en Revista Española de Antropología Americana n. ${ }^{\circ X I I I, ~ M a d r i d, ~}$ Universidad Complutense, 1983, pp.121-141; Steinar Saether, Identidades e Independencia en Santa Marta y Riohacha, 1750-1850, Bogotá, Instituto Colombiano de Antropología e Historia, 2005, pp.85-103.

24 Diego de Peredo, "Noticia historial de la provincia de Cartagena de las Indias año 1772", en Anuario Colombiano de Historia Social y de la Cultura n. ${ }^{\circ} 6-7$, Bogotá, Universidad Nacional, 1972, pp.118-154.

Dossier: Cuestionando las fuentes de archivos: padrones de población, familias y sociedades coloniales en Iberoamérica, ss. XVIII-XIX 
culas de las personas obligadas a repoblarse a mediados del siglo XVIII en ambas orillas del bajo curso del río Magdalena (provincias de Santa Marta y de Cartagena) solo señalaron a los cabezas de familias y a las personas que de ellos dependían, pero sin anotar sus calidades, ${ }^{25}$ exceptuándose las de los habitantes de los sitios de Nuestra Señora del Carmen de Barrancas, San Fernando de Carvajal y San Zenón (mapa 1), a quienes se les registraron la calidad de blancos, mestizos, zambos y cuarterones de mestizos. ${ }^{26}$

Algunos elementos de la tradición eclesiástica marcaron los padrones de 1777, tanto en las poblaciones neogranadinas como en otras colonias, en especial en aquellas que involucraron a los sacerdotes. En algunas colonias este criterio atravesó los censos realizados de acuerdo a la real orden de 1776. En los casos de los censos de Chile (1778) y de Nueva España los padrones los llevaron a cabo los sacerdotes, y se organizaron en torno a lo que hoy llamamos "estado civil": solteros/as, casados/as, viudos/as, párvulos/as, tal como puede verse en el resumen del padrón de Nueva España de 1779. ${ }^{27}$

En la Nueva Granada tenemos el censo de Molagavita, parroquia de la provincia de Pamplona, en el que se cruzó el estado civil (casado, viudo y soltero) y la calidad (blanco, indio, mestizo y mulato), ${ }^{28}$ como también en el del sitio de Plato (provincia de Santa Marta). ${ }^{29} \mathrm{O}$ donde se registraron solo a los vecinos cabezas de familias, mientras que las esposas, hijos, agregados y esclavos se anotaron como cifras escuetas, sin dar información sobre nombres, edades y ocupaciones.

\footnotetext{
${ }^{25}$ J osé de Mier (comp.), Poblamientos en la Provincia de Santa Marta. Siglo XVIII, tomo I, Bogotá, Colegio Máximo de la Academia de Colombia/Libreros Colombianos, 1987, pp.285-290, 311-320, 337-344, 347-351, 355-356.

${ }^{26}$ J . de Mier, Poblamientos en la Provincia de Santa Marta. Siglo XVIII, tomo I, pp.162-166 y 268270.

27 AGI, Mapas y Planos, Varios, 38.

${ }^{28}$ AGN, SC, CR-CVD, leg.8, f.674r.

${ }^{29}$ Ver el padrón de 1777 de Plato (provincia de Santa Marta), AGN, SC, fondo Curas y Obispos, leg.3, ff.946r.-949v.
} 


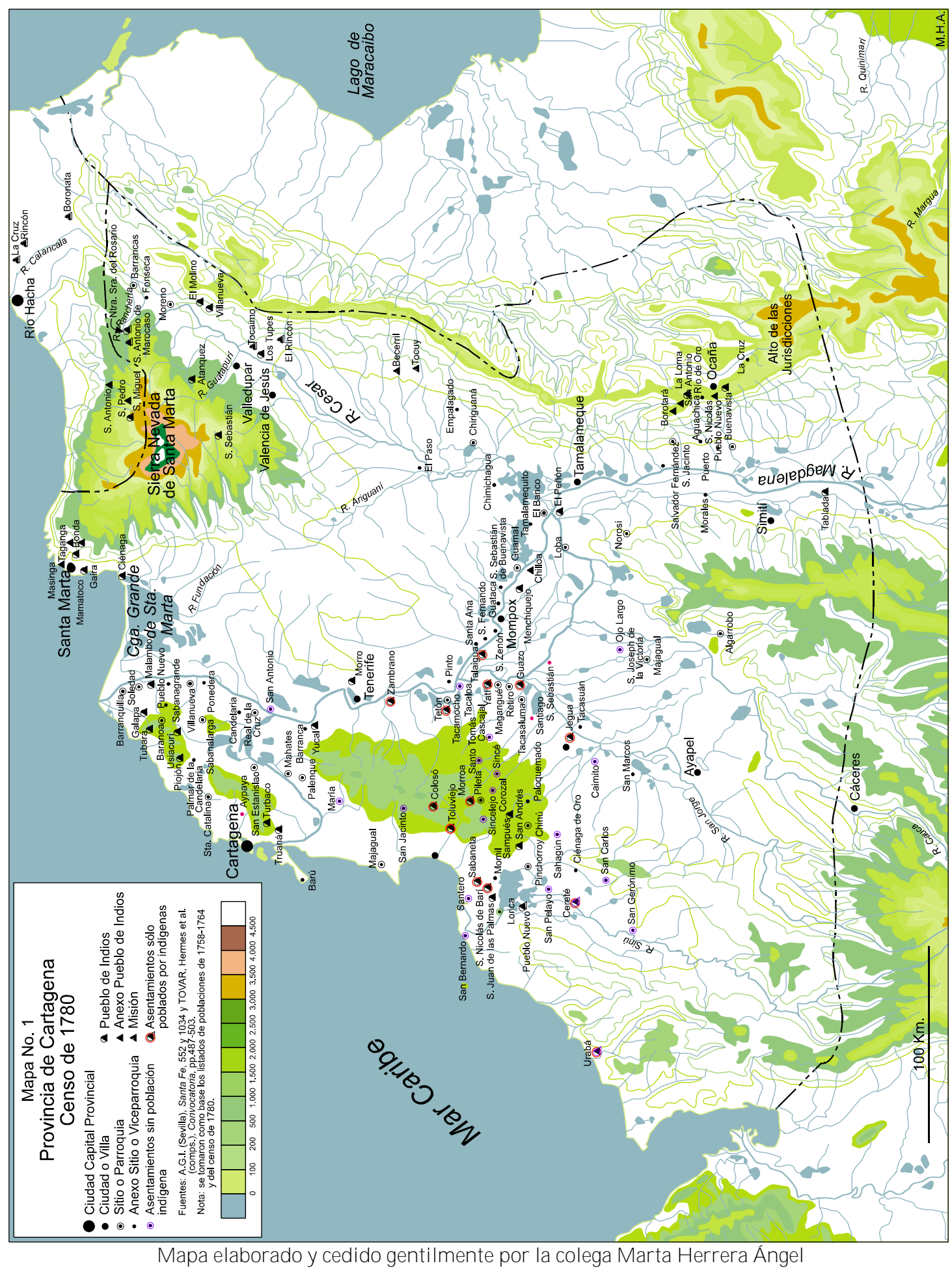

Dossier: Cuestionando las fuentes de archivos: padrones de población, familias y sociedades coloniales en Iberoamérica, ss. XVIII-XIX 
A estas tradiciones (eclesiástica representada en las matrículas de feligresías; y la civil materializada en los repartimientos de indios, visitas a la tierra para tasar tributos, y censos con fines impositivos y militares), en la segunda mitad del siglo XVIII se le sumaron lo que Alejandra Araya ha llamado la fase "proto-censal" de finales de ese siglo, caracterizada por técnicas más precisas de contabilización de la población y una tradición militar. ${ }^{30}$

Las distintas formas en que se realizaron los padrones de 1777 en las localidades y partidos de las provincias indican las dificultades que tenían las autoridades centrales de estas para coordinar una acción gubernamental. Mientras que en algunos casos los empadronadores dan muestras de haberse atenido a la disposición real de noviembre de 1776, en otros los resultados dan fe de haber seguido cada quien un criterio distinto. Otras disposiciones emitidas en medio del desarrollo del padrón insistieron en que las autoridades locales, de los partidos y de las provincias realizaran las visitas a las viviendas, pues no había dado resultados la experiencia de algunas poblaciones (por ejemplo, en la parroquia de El Colegio y en el pueblo de Anapoima, provincia de Mariquita) de citar a los habitantes durante algunos días para que se presentaran en los locales donde funcionaban las autoridades para proceder a empadronarlos. ${ }^{31}$ Algo parecido hizo el alcalde de Rionegro (provincia de Antioquia) en 1777 cuando solicitó que todos los habitantes

[...] concurran a mi juzgado a dar razón individual, de sus personas, de sus mujeres, hijos, hijas mayores, y párvulos, de sus esclavos y esclavas con la misma distinción y demás domésticos libres que tengan a su cargo, y de que se componga coda la familia de cada uno que fuere cabeza, y formando el padrón general se hará la colocación de clases como se previene, inclusive los forasteros que tienen actual residencia en este valle y sus familiares. ${ }^{32}$

En casi todos los virreinatos el desarrollo de los padrones recayó sobre los sacerdotes debido a la ascendencia que tenían sobre los habitantes de las poblaciones. En 1777 el virrey de Perú escribía a Madrid que había “[...] mandado a expedir

30 Alejandra Araya, "Registrar a la plebe o el color de las castas: 'calidad', 'clase' y 'casta' en la Matrícula de Alday (Chile, siglo XVIII)", en Alejandra Araya y Jaime Valenzuela (eds.), América colonial. Denominaciones, clasificaciones e identidades, Santiago de Chile, Pontificia Universidad Católica de Chile/Universidad de Chile/ Red Internacional del Libro, 2010, pp.331-362; "La Matrícula de Alday (1777-1778): imaginarios sociales y políticos en el siglo XVIII americano”, pp.15-33.

${ }^{31}$ AGN, SC, CR-CVD, leg.8, ff.225r.-226r.

32 Archivo Histórico de Antioquia, fondo Estadística y Censo, tomo 341, ff.304r.-v. Citado en Ana M. Pérez y Juan Montoya, "La invención de la población: salud y riqueza en el Nuevo Reino de Granada, 1760-1810”, en Secuencia n. ${ }^{\circ 78}$, México D. F., Instituto Mora, 2010, p.22.

Dossier: Cuestionando las fuentes de archivos: padrones de población, familias y sociedades coloniales en Iberoamérica, ss. XVIII-XIX 
a los señores obispos cartas de ruego y encargo, para que cada uno por lo respectivo a su diócesis, formase un padrón individual y circunstanciado que manifestase el número de personas de cada una de ellas, por las noticias y padrones que cada cura formase de las que comprendiese su doctrina, con expresión de las edades, estados y sexos [...]". ${ }^{33}$ Lo mismo sucedió en Nueva España, virreinato que tuvo dos censos paralelos: el de las autoridades ordinarias fundado en las unidades territoriales más simples como ciudades, villas, parroquias y pueblos, y el de las autoridades eclesiásticas basado en las jurisdicciones de las feligresías, las que comprendían varias poblaciones. ${ }^{34}$

Sin embargo, esa carga de obligaciones sobre los curas no siempre fue recibida con beneplácito por las autoridades eclesiásticas. En algunos lugares se presentaron problemas por competencias jurisdiccionales, pues las jerarquías católicas fueron reticentes a comprometer a los religiosos en el desempeño de esas labores. En 1778 el gobernador de la provincia de Popayán en la Nueva Granada demandaba del vicario eclesiástico de la ciudad de Pasto que,

[...] se podrá hacer dicho padrón con mejor arreglo valiéndome de los curas doctrineros me he visto precisado [...] a exhortar, rogar y encargar a Vuestra Merced Señor Vicario que en cumplimiento de su pastoral oficio y sin pérdida de tiempo provea y mande a los curas seculares de su dominio formen un exacto padrón de todos sus feligreses, con distinción de sexos, edades, estados, incluyendo los párvulos, autorizando cada cura bajo su firma el padroncillo de su pertenencia, sirviéndose presentarlo en este gobierno para que se remita a Su Majestad [...].35

El vicario le recordó al gobernador Beccaria que desde 1777 el ministro J osé Gálvez había determinado que esa labor debía ser desarrollada por los sacerdotes de la jurisdicción de Quito, o por el gobierno ordinario tal como lo especificaba la real orden de 1776.36

Esos conflictos de jurisdicciones entre el orden eclesiástico y el ordinario también se debieron a que los sacerdotes no se atenían a las recomendaciones dadas en la real orden de 1776. ${ }^{37}$ Los sacerdotes seguían el modelo de los censos de

33 AGI, Lima, leg.655, exp.78, f.1r.

34 E. Sánchez, Padrón del Arzobispado de México 1777,

35 AGN, SC, CR-CVD, leg.8, ff.616v.-617r.

36 AGN, SC, CR-CVD, leg.8, f.617v.

${ }^{37}$ AGN, SC, CR-CVD, leg.8, ff.238r.-239v.

Dossier: Cuestionando las fuentes de archivos: padrones de población, familias y sociedades coloniales en Iberoamérica, ss. XVIII-XIX 
feligresías (contar vecinos cabezas de familias y agregar cifras sobre esposas, hijos, agregados y esclavos). Por este motivo se les recordó que un decreto del ministro José Gálvez les ordenaba tener "[...] particular cuidado de formarlos con arreglo, y la misma claridad y distinción que se previene en la real orden de diez de noviembre de setenta y seis [...]", e informar a las autoridades civiles sobre los resultados de las diligencias encomendadas. ${ }^{38}$ Con base en estas atribuciones las autoridades de los partidos y de las provincias devolvieron algunos padrones de las poblaciones para que fueran corregidos, como sucedió con el de la parroquia de Molagavita (provincia de Tunja). ${ }^{39} \mathrm{El}$ descontento con la forma como los sacerdotes adelantaban estos encargos se prolongó hasta finales del siglo XVIII. En 1797 el virrey J osé de Ezpeleta informaba a las autoridades de Madrid que en Santa Fe de Bogotá se había creado una especie de junta de notables, la que entre varios propósitos pretendía adelantar

Los padrones que se hacen aquí anualmente por parte de los curas párrocos cometidos a unos sacristanes de poca instrucción en el asunto, absolutamente no sirven por los defectos de exactitud en el número, y especificación de matrimonios de hombres, mujeres, niños, oficio, calidad 0 habitación. Requisitos todos esenciales para que por parte de la policía reformen las listas más exactas del vecindario, de los barrios y de toda la ciudad. Las utilidades que de esto se siguen a un lugar culto son notoriamente conocidas y en el día se hace necesario en esta ciudad para formar el catastro de los que según la prima, y segunda regla del arbitrio deben contribuir por las casas tiendas de su pertenencia, tanto para facilitar el cobro a los cinco cobradores, sin que pierdan el tiempo en averiguar quién es, dónde vive, y a dónde se hallará, pues con la lista en la mano lo saben a punto fijo [...] Las listas se deben hacer con expresión de barrios, del número de las manzanas, empezando por la primera de las casas, que hay en ella, los nombres, estado, edad, oficio y calidad, en cuya posesión estuvieren los habitantes en la del número primero de sus hijos, sirvientes y comensales de uno y otro sexo, y así de los demás de la segunda casa, tercera, etc. Después se han de especificar en la misma lista las tiendas que hay en la primera manzana pertenecientes a la primera casa, segunda, tercera, etc., las que las habitan con la misma especificación y puntualidad que se ha dicho de edad, calidad y estado. ${ }^{40}$

Los censos detallados debían reposar en manos de las autoridades locales para que anualmente los actualizaran, ya fuese mediante nuevos padrones o por

38 AGN, SC, CR-CVD, leg.8, ff.2r.-4r.

39 AGN, SC, CR-CVD, leg.8, f.674r.

${ }^{40}$ AGI, Santa Fe, leg.791, exp.24, ff.13r.-v.

Dossier: Cuestionando las fuentes de archivos: padrones de población, familias y sociedades coloniales en Iberoamérica, ss. XVIII-XIX 
información sobre nacimientos, muertes y matrimonios suministrada por los sacerdotes y/ o por otros funcionarios de las administraciones locales. Las autoridades provinciales debían estar atentas para que las renovaciones de los padrones de las poblaciones bajo sus jurisdicciones se realizaran "[...] guardando el mismo mé todo a fin de que formando después uno general del todo de ella me lo dirija con tanta anticipación cuanta es necesaria para que yo pueda hacer formar aquí uno general de todo el virreinato [...]". ${ }^{41}$ Es decir, con base en los padrones de cada población las autoridades de los partidos y de las provincias debían elaborar los cuadros resúmenes que eran del interés de las autoridades centrales del virreinato. Estos debían contener,

[...] todos los lugares, villas, pueblos y parroquias de su distrito, y en cada una el número de habitantes, con distinción de clase y condición, sacando el total en guarismo, que remitirá con las diligencias, dejando copia para gobierno en lo venidero en un libro, verificándolo siempre al fin de cada año, con apercibimiento de que cualquier omisión se castigará severamente. ${ }^{42}$

Si para el caso del Nuevo Reino de Granada no están del todo claro los detalles de la organización del censo de 1777, el del arzobispado de Ciudad de México si permite ver detalles, los que quizá puedan ilustrar un poco. En efecto, el instructivo dirigido el 10 de mayo de 1777 por el arzobispo de Ciudad de México a los sacerdotes es quizá el que mejor da una imagen acerca de las diferencias entre los padrones particulares de cada población y/ o feligresía y los resúmenes que debían enviarse a la administración central:

Se podrán así mismo en el padrón sus familias, vicarios y demás clérigos de cualquier orden. Los españoles se pondrán con separación de los indios y demás castas, y harán igual separación de los castizos, mestizos, mulatos, lobos, negros, etc. Al fin del Padrón harán un resumen en esta forma: tantos clérigos, o personas eclesiásticas, inclusos el cura o curas, sus vicarios y demás clérigos; tantas familias de españoles y tantas personas de todas edades. De estas, tantos casados, tantos viudos, tantas viudas, tantos párvulos, tantos solteros, tantas solteras, inclusas las doncellas, porque en España se entiende por soltera la que está libre y suelta de Matrimonio y no es viuda. Tantas familias de indios, tantas personas, tantos casados, tantos viudos, tantas viudas, tantos párvulos, tantos solteros, tantas solteras; tantas familias de castizos y tantas Personas con la separación dicha de casados, viudos, párvulos, solteros; y lo mismo se hará con las demás castas que hubiere en cada curato. A lo último de cada resumen se

41 AGN, SC, CR-CVD, leg.6, f.310r. y v.

42 AGN, SC, CR-CVD, leg.8, ff.224v.-225r.

Dossier: Cuestionando las fuentes de archivos: padrones de población, familias y sociedades coloniales en Iberoamérica, ss. XVIII-XIX 
sumarán al lado izquierdo todas las familias que deben numerarse desde el principio del padrón, y al derecho todas las personas que igualmente numerarse de todas edades y calidades, castas, y estados que haya en cada curato; de manera que una suma sea de todas las familias y otra de todas las personas expresando que estas están comprendidas tantas Personas eclesiásticas, tantos casados, tantos viudos, tantas viudas, tantos párvulos, tantos solteros y tantas solteras de todas edades, castas y calidades. ${ }^{43}$

A comienzos de 1778 el virrey Manuel Antonio Flórez se quejaba por la demora en el envío de los cuadros resúmenes de las poblaciones, partidos y provincias neogranadinas ${ }^{44}$ y explicaba que el interés de las autoridades de Santa Fe de Bogotá radicaba en los sumarios y no en los padrones exhaustivos:

Reconocidos los padrones que se me han remitido de algunas provincias [...] he advertido que contiene demasiada prolijidad, como es la de los nombres de cada persona, y otras menudencias que antes que claridad manifiestan confusión. Para evitar estas, y que se ejecute con más facilidad he mandado formar el planecillo o estado que incluyo para que sirva de pauta, y no halla otra cosa que hacer, sino llenar las casillas que van designadas en él con las sumas que correspondan a cada estado, clase y casta [...]. ${ }^{45}$

También demandaba de las autoridades provinciales vigilar para que ciudades, villas, parroquias y pueblos se guardara

[...] el mismo método a fin de que formando Vuestra Merced después uno general de toda ella me lo dirija con tanta anticipación cuanta es necesaria para que yo pueda hacer formar aquí uno general de todo el virreinato, y dirigirlo en el mes de diciembre de cada año a Su Majestad, bien entendido que habrá de comenzarse con el presente de 1778 porque se podrá practicar con más regularidad y arreglo y conforme al espíritu de la citada real orden [...]. ${ }^{46}$

\footnotetext{
43 "Instrucción que deban observar todos los Señores Curas de este Arzobispado para formar los Padrones de sus Feligreses, con la formalidad y distinción que S.M. previene en su Real orden de 10 de Noviembre de 1776 años”. Inserta en E. Sánchez, Padrón del Arzobispado de México 1777, p.73.

44 Los resúmenes del censo de 1777 de las provincias de Veragua y Alhange (actual Panamá) sólo fueron elaborados en el segundo semestre de 1778. AGN, Sección Colecciones, Enrique Ortega Ricaurte (en adelante SCS., EOR), Caja 12, f.7r.

45 AGN, SC, CR-CVD, leg.6, f.310r. yv.

46 AGN, SC, CR-CVD, leg.6, f.310r. y v.
}

Dossier: Cuestionando las fuentes de archivos: padrones de población, familias y sociedades coloniales en Iberoamérica, ss. XVIII-XIX 
El formato diseñado por la administración del virrey Flórez constaba de 5 columnas para los eclesiásticos, blancos, indios, libres de varios colores y esclavos de varios colores respectivamente. La de los eclesiásticos se subdividía en "seculares, regulares, legos y religiosas". Las 4 restantes en "hombres casados, hombres solteros incluso los párvulos, mujeres casadas y mujeres casadas incluso las párvulas”. Luego seguían unos cuadros resúmenes en los que se consignaban el "total de matrimonios"; "hombres de todas las clases, castas y estados incluso los párvulos; mujeres de todas las clases, castas y estados incluso las párvulas". Estos cuadros se subdividían en "eclesiásticos, blancos, indios, libres y esclavos". Esto formatos continuaron utilizándose durante lo que restaba de dominio colonial, pues en 1789 en su relación de mando el virrey Antonio Caballero y Góngora informaba que los formatos hechos por el virrey Flórez habían servido para para establecer criterios unificados en la recolección de información. ${ }^{47} \mathrm{Y}$ en ese mismo año el también virrey Francisco Gil y Lemos informaba a su sucesor, J osé de Ezpeleta, que había entregado formatos al obispo de Cartagena para que los distribuyera entre los sacerdotes de esa provincia con el fin de que adelantaran los padrones de forma más fácil ${ }^{48}$ para facilitar llevar a cabo el resumen general de cada provincia y de todo el virreinato. Como lo veremos más adelante esto tendría sus secuelas en las formas de la presentación de la clasificación socio-racial de la población, como también en la presentación de los resultados del censo.

Tanto la elaboración como el recibo de estos cuadros fueron motivos de desavenencias entre las autoridades centrales del virreinato, los gobernadores provinciales y los corregidores de partidos, por la falta de uniformidad en la recolección y elaboración de los datos acorde con las expectativas de las autoridades de Santa Fe de Bogotá, por la tardanza en la realización de los empadronamientos y por el no envío de muchos listados a aquellas autoridades. Un primer conflicto se dio en torno a quienes debían centralizar los padrones adelantados por los curas. A finales de 1777 el arzobispo de Bogotá, don Agustín Alvarado y Castillo, recibió ciento trece padrones confeccionados por sacerdotes, y los llevó consigo a España, obligando a su reelaboración. ${ }^{49}$

Con las autoridades subalternas de las provincias y partidos también hubo problemas, ya fuese por negligencias en los levantamientos, por dificultades debi-

\footnotetext{
47 Germán Colmenares, (editor), Relaciones e informes de los gobernantes de la Nueva Granada, tomo I, Bogotá, Banco Popular, 1989, p.414.

48 AGI, Santa Fe, leg.578, exp.29, f.9r.

49 AGN, SC, CR-CVD, leg.8, ff.246r.
}

Dossier: Cuestionando las fuentes de archivos: padrones de población, familias y sociedades coloniales en Iberoamérica, ss. XVIII-XIX 
das a las precarias vías de comunicaciones, por lo extenso del territorio a cubrir y por las resistencias de los habitantes que asociaban a los empadronamientos a la imposición de cargas fiscales. ${ }^{50}$ Se trató de situaciones recurrentes con todos los padrones del último cuarto de ese siglo. Ante los requerimientos de las autoridades locales y virreinales el teniente de la villa de El Socorro informaba en 1778 que había tardanza en la realización de los padrones de las poblaciones de esa jurisdicción y que solo había podido hacer el de la cabecera, y que este estaba "[...] muy diminuto porque las gentes se han negado a declarar la mayor parte de sus familias, creyendo que el padrón se dirige a imponer algún servicio real o personal, y porque no se les gravase han minorado el número de personas". Señalaba que buena parte de los problemas y de la tardanza en realizar los padrones en toda la jurisdicción de esa villa se debieron a las negligencias del cabildo de esa localidad. 51

De igual forma sucedió que la población de algunos sitios se vio reducida debido a que los propietarios de esclavos no informaron sobre estos, tal como lo comunicó el gobernador de la provincia de Neiva a propósito del padrón de $1778.52 \mathrm{~A}$ finales de del año anterior el encargado del padrón entre los indios de la provincia de Pasto se defendió de un intento de amonestación económica por la tardanza en la realización y envío de los padrones, notificando que varias comunidades de indios se habían levantado imposibilitando llevar a feliz término la tarea encomendada. ${ }^{53} \mathrm{Y}$ en 1780 nuevamente se vio precisado a defenderse de ser multado por supuesto incumplimiento aduciendo tanto la falta de apoyo que debió brindarle la gobernación luego del levantamiento de los pueblos de indios de Cotacache y Otavalo. 54

Además, la ignorancia de las órdenes emanadas del virrey, lo que consideraba cada uno de estos altos funcionarios, la premura del tiempo y las desavenencias

\footnotetext{
50 Sobre las dificultades para llevar a cabo el censo de 1777 ver las exposiciones que elevaron los gobernadores de las provincias de Guayaquil: AGN, SC, CR-CVD, leg.6, ff.435r.-437v.; Panamá: AGN, SC, fondo Milicias y Marina (MM), leg.147, ff.954r.-956v.; Veraguas: AGN, SC, MM, leg.147, ff.946r.953v.; Portobelo: AGN, SC, MM, leg.147, ff.904r.-907v.; Isla Margarita: AGN, SC, MM, leg.141, ff.181r.$182 \mathrm{v}$.

51 AGN, SC, fondo Visitas-Santander, leg.4, ff.950r.-v.

52 AGN, SC, Miscelánea, leg.64, f.326r.

53 AGN, SC, CR-CVD, leg.6, ff.311r.-312r. Sobre las relaciones entre padrones, temor a impuestos y levantamientos sociales a finales de 1777 en los pueblos indígenas de Cotacache y Otavalo (Ecuador), ver: Cristina Borchart, El corregimiento de Otavalo: Territorio, población y producción textil (1535-18o8), Quito, Universidad de Otavalo, 2007, pp.160-165.
}

54 AGN, SC, CR-CVD, leg.8, ff.614r.-651v.

Dossier: Cuestionando las fuentes de archivos: padrones de población, familias y sociedades coloniales en Iberoamérica, ss. XVIII-XIX 
entre las distintas autoridades, dieron pie para que los censos de las poblaciones neogranadinas tomaran características distintas. En 1780 las autoridades de la ciudad de Salazar de las Palmas (provincia de Pamplona) se excusaban porque el padrón de ese año no se hizo con base en el modelo que se les había enviado, y por haber remitido "[...] por nosotros una confusa lista con nombre de padrón, dando a conocer no haberla mandado conforme al plan que Su Majestad ordena, de que se sigue el concepto de inobediencia [...]". ${ }^{55}$ Y esto sucedía pese a que el censo de 1777 de esa población había sido objetado por don Francisco Moreno y Escandón por considerarlo muy engorroso al atenerse al formato de los padrones eclesiásticos.

En el caso de Cartagena solo el censo del barrio de Santo Toribio, uno de los cinco barrios que formaban la ciudad (no se ha podido encontrar el del barrio de Santa Catalina), siguió a pie juntillas la orden real de 1776 y registró nombres de cada miembro de las familias, edades, estado civil, oficios y condiciones socioraciales. ${ }^{56}$ Los de los barrios de San Sebastián y La Merced lo hicieron de forma parcial y el del barrio de Getsemaní no incluyó referencia alguna a la condición socio-racial de las personas. ${ }^{57}$ Es decir, de esa orden real que demandaba especificar clases, estados y calidades no quedaba nada. Las razones de esas disparidades en los padrones de esta ciudad las explicaremos más adelante cuando nos refiramos a los censos de las poblaciones de los partidos de Tierradentro y de Mahates, en jurisdicción de la provincia de Cartagena.

Algunas de esas situaciones obligaron a las autoridades de Santa Fe de Bogotá a llamar la atención a los gobernadores provinciales, y estos se excusaron achacando incumplimiento por parte de sus subalternos locales. ${ }^{58}$ A comienzos de 1780 el visitador don J uan Antonio Gutiérrez de Piñeres informaba al virrey Flórez que la tardanza en la realización del censo de la provincia de Tunja de ese año no se debía a negligencia del corregidor de esa provincia si no a "[...] los estorbos y dificultades que propusieron los subalternos". ${ }^{59}$ En 1784 don Domingo Antonio Lozada, alcalde ordinario de la villa de San Benito Abad comisionado por don Antonio de la Torre y Miranda para levantar en menos de una semana los censos de Sincelejo, Sahagún, Chinú y Sampués (provincia de Cartagena), informó que con muchas difi-

55 AGN, SC, MM, leg.141, f.45r.

56 AGN, SC, Miscelánea, leg.39, ff.1004r.-1078v.

57 AGN, SC, Miscelánea, leg.44, ff.945r.-958v.; AGN, SC, CR-CVD, leg.8, ff.75r.-134v., 132r.-164v.

58 En la provincia de Mariquita se continuaron presentando problemas para levantar los padrones de 1778 y 1779. AGN, Sección Archivos Anexos, fondo I, subfondo 2, leg.1, ff.169r.-170r.

${ }^{59}$ AGN, SC, Miscelánea, leg.82, f.971r.

Dossier: Cuestionando las fuentes de archivos: padrones de población, familias y sociedades coloniales en Iberoamérica, ss. XVIII-XIX 
cultades solo se había adelantado el padrón de la primera población debido a que “[...] habiéndolo encargado al Notario don Juan de Avendaño se me excusó con frívolos pretextos, devolviéndome la orden, por lo que me fue preciso costear un sujeto confidente para que pasase a Sincelejo a sacar el padrón [...]”. ${ }^{60}$

La condición de frontera de muchos de los territorios neogranadinos, la dispersión del poblamiento y el escaso control que ejercía la administración colonial fueron impedimentos para que los padrones se realizaran de la mejor forma posible. En 1777, Francisco Antonio Moreno y Escandón, fiscal de la Real Audiencia de Santa Fe, escribió:

[...] que lo defectuoso de la población, distancias fragosas en que muchos habitan en los desiertos y la falta de civilidad y reglas de sociedad, que se advierte con dolor en el distrito de este virreinato, dificultan notablemente la formación exacta de los padrones que por clases y por separación indiquen el número de habitadores de ambos sexos, con inclusión de párvulos, pero sin verificación no solo es útil y conducente al acierto del gobierno, sino que mandándolo Su Majestad se hace del todo preciso que se ejecute y que para su logro se procuren vencer todas las dificultades, que ocurran en la inteligencia de que con su repetición se ratificaran con el tiempo los defectos, que en el principio fueren inevitables sirviéndole a los mismos gobernadores y jueces de auxilio estas noticias para arreglar sus providencias y conocer a los súbditos. ${ }^{61}$

Y un decenio más tarde, en 1789 el virrey Antonio Caballero y Góngora se expresaba sobre esos problemas de la siguiente forma:

[...] por mucho cuidado que se quiera poner en la formación de un padrón ge neral, jamás se alcanzaran a comprender las ocultas rancherías [...]. Sin embargo, siempre se ha intentado y se ha conseguido, a lo menos un cómputo prudencial. [...] después de las inquietudes del reino [revuelta comunera], la malicia de algunos y la ignorancia de los más hizo extender la voz de que esta operación era dirigida a un nuevo impuesto, con 10 que los padres ocultaban la mitad de su familia si no podían esconderse en los montes mientras el empadronamiento. ${ }^{62}$

${ }^{60}$ AGN, SC, MM, leg.141, f.43r.

61 Archivo Histórico de Antioquia, Reales Cédulas, tomo 2, ff.347r.-v. Citado en A. M. Pérez y J . Montoya, "La invención de la población: salud y riqueza en el Nuevo Reino de Granada, 1760-1810", p.24.

62 G. Colmenares (ed.), Relaciones e informes de los gobernantes de la Nueva Granada, t.I, p.404.

Dossier: Cuestionando las fuentes de archivos: padrones de población, familias y sociedades coloniales en Iberoamérica, ss. XVIII-XIX 


\section{Censos, clasificaciones socio-raciales e intereses imperiales}

A los problemas descritos se le sumaron otros relacionados con el hecho de tener que aplicar la orden de la Corona en unos contextos caracterizados por la gran diversidad socio-racial de las sociedades locales, provinciales y virreinales que integraban el imperio. Así, mientras que hasta cierto punto era fácil determinar los "estados" (soltero/a, casado/a, viudo/a) y "clases" (en algunos casos entendidas como ocupaciones, y en otros como el color), respecto de la determinación de las "castas" (en muchos censos registradas como las calidades y/ o el color) el trabajo se hacía mucho más difícil por los distintos factores que intervenían y porque se ponía en juego la condición social de las personas y familias. ${ }^{63}$

El propósito era representar la taxonomía social de ese entonces en unos datos sobre las calidades de las personas y de expresar sus representatividades en valores numéricos. No se trataba de un ejercicio nuevo pues en la elaboración de esas taxonomías sociales habían tenido un lugar destacado las prácticas escriturarias de contabilización de la población realizadas desde el poder (matrículas de indios, de almas de confesión, de gentes obligada a repoblarse y los listados de milicianos). A diferencia de otra documentación oficial y eclesiástica escrita que también contenían datos sobre las calidades de las personas, matrículas, padrones y listados de milicianos eran hechos con los expresos propósitos de definir estatus y la posición de cada individuo y familia en el orden social, y con ello establecer derechos y deberes.

En la elaboración de estas intervinieron diversos aspectos claves para el orden colonial: las relaciones con Dios (estado "civil": matrimonios y registro por familias), con el poder (vivir poblado y ocuparse en trabajo honesto), la social (calidades) y la política (buen vasallo, libertad, vecindario, o en caso contrario tributario, esclavo). Las formas de entender y ordenar esas relaciones dieron origen a unos lenguajes que expresaban diferencias materializadas en prácticas y jerarquías sociales. Una jerarquía primaria basada en la clasificación de blanco, indio y negro fue transversalizada, tanto por los mestizajes que resultaron del cruces de personas de esas condiciones, como por otros criterios de ordenamiento social (distinguido y plebe; oficios honestos y oficios viles; de buen y de mal vivir), los que a su vez incidieron en aquel ordenamiento social vertical.

63 David Brading, "Grupos étnicos, clases y estructura ocupacional en Guanajuato colonial (1792)”, en Historia Mexicana vol.21, n. ${ }^{\circ 3}$, México D. F., El Colegio de México, 1972, pp.461-462.

Dossier: Cuestionando las fuentes de archivos: padrones de población, familias y sociedades coloniales en Iberoamérica, ss. XVIII-XIX 
Esto dio como resultado una imbricada textura social que ya para el siglo XVIII generaba dificultades y potenciales conflictos al momento de clasificar a una persona en una u otra categoría. Por eso, la real orden de noviembre de 1776 que obligaba a realizar padrones en todas las posesiones coloniales de América y en las Filipinas no podía especificar los términos de cada categoría socio-racial a los que se acogieran los empadronadores para definir las calidades de las personas. Y en los virreinatos y en las capitanías tampoco era posible definir cada categoría socioracial porque con el paso del tiempo se había vuelto muy compleja la variedad de los grupos sociales como resultado del cruce entre blancos, indios y negros y de todas sus mixturas. Además, también intervenían otros factores de clasificación social que habían hecho muy difusas las categorías primarias de ordenamiento socioracial, surgiendo calificaciones particulares para caracterizar la calidad social de las personas y de los grupos, o tomando los conceptos distintos significados. ${ }^{64}$ Esto explica que los términos genéricos de la orden real para empadronar a todas las "clases, estados y castas, incluso los párvulos" permitieran que en muchos casos se emplearan las categorías socio-raciales de cada población.

En fin, para evitar tener que enviar a Madrid una documentación que contuviera las diversidades de categorías sociales para cada virreinato, capitanía e intendencia, ${ }^{65}$ la autoridades virreinales y las de Madrid acudieron a los que practicaban desde hacía mucho tiempo: presentaron informes que integraban categorías y compendiaban los datos de forma sucinto. Esa vieja experiencia se empezó a hacer evidente desde las llamadas relaciones histórico-geográficas que demandó la corona de parte de las autoridades ordinarias y del clero de las colonias. Una lectura de las correspondientes a la Audiencia de Quito relativas a los siglos XVI al XVIII deja ver una clara tendencia a la simplificación. Para mediados del último siglo de dominio colonial las relaciones geográficas presentadas a la corona por funcionarios y prelados eclesiásticos generalizaban el uso de la expresión "españoles, indios mes-

\footnotetext{
${ }^{64}$ Los listados de clasificaciones de los virreinatos de Nueva España y Perú pueden leerse en M. Mörner, La mezcla de razas en la historia de América Latina, pp.60-72.

65 En España se empleaban algunas denominaciones parecidas a las de las colonias para designar a las gentes de color descendientes de esclavos. Baltasar Fra. Molinero, "Ser mulato en España y América: discursos legales y otros discursos literarios", en Berta Ares-Queija y Alessandro Stella, (coordinadores), Negros, mulatos, zambaigos. Derroteros africanos en los mundos ibéricos, París/Sevilla, Centre National de la Recherche Scientifique/ Escuela de Estudios Hispano Americanos, 2000, pp.123-147. Aún en el siglo XVIII los descendientes libres de estos esclavos eran marginados, como se quejaba el alcalde mayor de la población de Medina de las Torres (Badajoz) por la exclusión para el servicio en ejército de los mulatos que abundaban en esa provincia. AGS, SDG, leg.7320, exp.40, ff.1r.-8v.
}

Dossier: Cuestionando las fuentes de archivos: padrones de población, familias y sociedades coloniales en Iberoamérica, ss. XVIII-XIX 
tizos y gentes de todas las castas"; "españoles, mestizos, mulatos y otras castas". ${ }^{66}$ En otros casos, como lo hizo el gobernador de la provincia de Guayaquil en 1765, se referían a los habitantes en términos genéricos como españoles, indios, negros " $\mathrm{y}$ sus descendientes"; también especifica algunos sectores sociales (españoles, indios) y luego agregaba una cantidad de "personas de todas clases de gentes", para señalar al conjunto de castas resultados del cruce de estos. ${ }^{67}$

Esto estaba a tono con los esfuerzos que se hicieron en Madrid para ordenar la comprensión que debía tenerse de la realidad social de las colonias en función del diseño de las políticas para las colonias y del ordenamiento de la legislación. Luego de una primera fase de emisión de una enorme cantidad de disposiciones, hubo esfuerzos dirigidos a ordenarla y para ello se obviaron muchos aspectos de aquella realidad y se presentaron ciertas imágenes de conjunto. Por ejemplo, en el ordenamiento de la gran cantidad de leyes indianas realizado a mediados del siglo XVII varios autores de tratados jurídicos y políticos que tuvieron buena acogida en los medios letrados y administrativos del imperio español habían reducido el mundo social a unas pocas categorías. ${ }^{68}$ En 1647 J uan de Solórzano y Pereira, quien había vivido en Lima a comienzos de esa centuria, publicó su Política Indiana en la que con fines de facilitar la administración del imperio recogía algunas categorías socio-raciales que tenían aplicación en esa colonia. Indios, blancos criollos, mestizos, zambahigos, morenos o pardos (resultado de negro y negra libre), mulatos (blanco y negra), negros libres, negros esclavos y cimarrones son descritos en función de las mezclas y de las supuestas características morales que de ellas devenían, de la legitimidad de la unión conyugal, de la educación, de las actitudes frente al trabajo y la tributación y de las posibilidades para que ocuparan ciertos cargos en la república. ${ }^{69} \mathrm{Su}$ texto, que cotejaba sus conocimientos directos con los de otros tratadistas y con la legislación indiana, sentó las líneas generales de las imágenes que

66 Pilar Ponce, (ed.), Relaciones histórico-geográficas de la Audiencia de Quito. Siglos XVI-XIX, tomo II, Madrid, Consejo Superior de Investigaciones Científicas, 1991, pp.330, 338-339, 344. Énfasis nuestros.

67 P. Ponce, Relaciones histórico-geográficas de la Audiencia de Quito (siglos XVI-XIX), tomo II, pp.362, 364, 365.

68 En 1609 vio la luz pública la obra Comentarios Reales en la que Garcilaso de la Vega presentó a los blancos clasificados en europeos y criollos; mulatos como resultados del cruce de negro e india; cholos como hijos de mulato y mulata; tresalbos como productos del cruce entre indio y mestiza; cuatralbos como hijos de blanco y mestiza; y mestizos (o montañés) como productos de español e india. Garcilaso de la Vega, Comentarios reales, tomo II, Caracas, Biblioteca Ayacucho, 1976, pp.265-266.

${ }^{69}$ J uan de Solórzano y Pereyra, Política indiana, vol.1, libro primero, capítulo Xxx, Madrid, Matheo Sacristán, 1736, pp.215-220. En: http:// goo.gl/c7KtKC.

Dossier: Cuestionando las fuentes de archivos: padrones de población, familias y sociedades coloniales en Iberoamérica, ss. XVIII-XIX 
se tenían en Madrid y en las altas esferas de la administración imperial sobre las "principales" categorías socio-raciales de algunas colonias hispanoamericanas.

Como ha anotado Berta Ares-Queija a propósito de las genealogías de las categorías socio-raciales en el Perú del siglo XVI,

De todas maneras, a la hora de hablar de la población de origen mixto lo más común era recurrir a expresiones englobantes del tipo 'mestizos, mulatos y de más castas', que sin duda se corresponden mucho mejor con la imagen generalizadora que se desprende de cartas, informes, relaciones, cédulas [...], esto es, del discurso oficial predominante..$^{70}$

En Venezuela el obispo Mariana Martí, en su visita pastoral que realizó entre 1771 y 1784 a 350 poblaciones (12 ciudades, 9 villas y 190 pueblos: de estos, 95 son doctrinas de indios, 29 misiones, y 66 de españoles) del área centro-occidental de esa capitanía, al dar los datos demográficos y de las calidades de los habitantes de las poblaciones siempre escribió en cada una lo siguiente:

Matrícula o padrón de los habitantes dentro del distrito de este pueblo. Conforme al método e individualidad mandado observar por circular novísima, con advertencia de que en la distinción de clases van colocados los mestizos en la de los blancos y los zambos en la de los negros. ${ }^{71}$

Pero cuando particularizaba sobre situaciones de cada pueblo acudía a otras categorías:

Bernardino Requena, blanco, soltero, vive mal con una mulata, hija de Joseph Matute, soltera. [...] J oseph Fernández, blanco, casado, vive mal con una samba que tiene en su casa del Socorro, distante de acá como unas veinte leguas. [...] Andrés Arévalo, mestizo o mulato, soltero, vive mal con Francisca Arévalo, su prima hermana, soltera. ${ }^{72}$

Por eso, a comienzos del siglo XVIII algunas administraciones coloniales hicieron esfuerzos por dar a conocer algunas particularidades de las configuraciones

\footnotetext{
70 Berta Ares-Queija, “Mestizos, mulatos y zambaigos (virreinato del Perú siglo XVI)”, p.84; "Las categorías del mestizaje: desafíos a los constreñimientos de un modelo social en el Perú colonial temprano", en Histórica vol.XVIII, n. ${ }^{\circledR}$ 1, Lima, Pontificia Universidad Católica de Perú, 2004, pp.204-205.

71 Mariano Martí, Documentos relativos a su visita pastoral de la Diócesis de Caracas, tomo VI, Caracas, Biblioteca de la Academia Nacional de la Historia, 1998, p.12. Cursivas nuestras.

72 M. Martí, Documentos relativos a su visita pastoral de la Diócesis de Caracas, tomo II, pp.488494. Cursivas nuestras.
}

Dossier: Cuestionando las fuentes de archivos: padrones de población, familias y sociedades coloniales en Iberoamérica, ss. XVIII-XIX 
socio-raciales de sus sociedades. Por ejemplo, el Duque de Linares, virrey de Nueva España, había hecho pintar los cuadros de castas con el fin de mostrar a las autoridades centrales del imperio la complejidad de las mezclas y de los tipos humanos que se habían generado en ese virreinato. A mediando esa centuria algo parecido hizo el obispo auxiliar de Puebla mandando a pintar cuadros de castas en "[...] un lienzo dividido en 16 tableros, para remitir a España, y en cada uno va una mezcla con tres personas, padre, madre e hijo [...]". ${ }^{73}$ Luego se hicieron otras series de cuadros en ese virreinato y en el del Perú. En 1770 el virrey Amat del Perú envió a Madrid 20 cuadros de pinturas de las castas de ese virreinato al gabinete de historia natural que se estaba formando en la capital del Imperio. La carta remisoria de los cuadros decía que como ilustración de uno "[...] de los ramos principales de raras producciones que ofrecen estos dominios la notable mutación de aspectos, figura y color que resulta en las sucesivas generaciones de la mezcla de los indios y negros, a que suelen acompañar proporcionalmente las inclinaciones y propiedades [...]". ${ }^{74}$

Aún la historiografía sobre las clasificaciones socio-raciales y los cuadros de castas no ha llegado a conclusiones definitivas sobre lo que a los ojos de las autoridades centrales del imperio y de los habitantes de las colonias podía significar la diversidad de las calidades sociales. Es posible que esto dijera poca cosa a esas autoridades más interesadas en unas imágenes de conjunto para el diseño de sus políticas imperiales. Esto último es un aspecto a tener en cuenta para entender la organización de los censos del último cuarto del siglo XVIII, pues explica el interés en la elaboración de resúmenes y cuadros en los que la diversidad de categorías sociales se agruparon con base en criterios raciales simples (blancos e indios y castas de todos los colores), estado (eclesiásticos) y de acuerdo a quienes disfrutaban o no de la libertad, es decir libres, esclavos e indios tributarios. ${ }^{75}$

Allí donde los padrones se desarrollaron acogiéndose literalmente a las exigencias que señalaba la real orden de 1776 se anotaron las especificidades que asumieron las sociedades locales y provinciales, entre ellas las categorías socioraciales. Sin embargo, en los censos de las poblaciones se impuso el requerimiento de las autoridades centrales del virreinato que hemos señalado páginas atrás, y este fue el que organizó los distintos resúmenes que se hicieron por provincias y para todo el virreinato de la Nueva Granada. Por ejemplo, en 1779 don J osé María Cam-

\footnotetext{
73 Efraín Castro Morales, "Los cuadros de castas de la Nueva España”, en Jahrbuch für Geschichte von Staat, Wirtschaft, Besellschaft Lateinamerikas n. ${ }^{\circ} 20$, Viena, Universität Graz, 1983, pp.7-8.

${ }^{74}$ AGI, Lima, leg.652, exp.57, ff.1r.-v.

75 Ver los censos de los pueblos de indios de Menchiquejo y Chilloa situados cerca de Mompox. AGN, SC, fondo Poblaciones, leg.10, ff.539r.-540v.
}

Dossier: Cuestionando las fuentes de archivos: padrones de población, familias y sociedades coloniales en Iberoamérica, ss. XVIII-XIX 
pusano Lanz, visitador de la provincia de Tunja informaba a las autoridades de Santa Fe de Bogotá haber remitido los modelos a los cabildos de las ciudades y villas de su jurisdicción para que levantaran los padrones, y terminaba diciendo "[...] inmediatamente lo verifiquen formaré el general de la provincia y lo remitiré a esta superioridad". ${ }^{76}$

No conocemos un documento en el que las altas autoridades de la Nueva Granada explicaran la clasificación de los resúmenes de los padrones provinciales en "eclesiásticos, blancos, indios, libres de todos los colores y esclavos de todos los colores". ${ }^{77}$ En un artículo anterior nos hemos referido a los argumentos de la historiadora Margarita Garrido sobre la categoría "libres de todos los colores". ${ }^{78}$ A nuestro parecer el uso de esta metáfora es un reflejo de dos hechos que deben subrayarse. Por un lado por peso y el creciente protagonismo social y político adquirido por los sectores libres entre la población del virreinato, desplazando las representatividades de indios y esclavos. Y atravesando esos elementos se encontraba la demanda de un conocimiento que tuviera la capacidad de agrupar y ofrecer categorías analíticas que pudieran colocarse por encima de un imbricado tejido de diferencias sociales.

En efecto, los mestizos de distintas condiciones venían rompiendo el tegumento de una sociedad que se había jerarquizado a partir de un orden socio-racial diferenciado. Los efectos que fueron produciendo en la sociedad del siglo XVIII se expresaron en la generalización del empleo del término de "calidad" que agrupaba un conjunto de atributos para referirse a la posición social de las personas. Esos atributos pueden resumirse como la unión de criterios de raza, clase y estatus. ${ }^{79}$ Por eso, antes del siglo XVIII esa metáfora era impensable. Por otra parte también fue expresión de la consolidación de un nuevo episteme en el que se impuso un criterio valorativo de la libertad a nivel discursivo. La unión de la alarma que causaba el

76 AGN, SC, Miscelánea, leg.82, f.12v.

77 Asiste la razón a Adolfo Meisel y María Aguilera cuando afirman que "libres de todos los colores" "[...] era una categoría residual y allí se incluía a todos aquellos que no fueran blancos, indígenas o esclavos. [...] en ese grupo estaban incluidos todos los matices de las diversas mezclas raciales. También se contabilizaban dentro de este grupo a los negros libres". Tres siglos de historia demográfica de Cartagena de Indias, Cartagena, Banco de la República, 2009, p.23.

78 S. P. Solano, "Padrones de población e historiografía sobre la configuración socio-racial hispanoamericana del siglo XVIII", pp.154-155.

${ }^{79}$ Sergio Paolo Solano, "Raza, trabajo, liberalismo y honorabilidad en Colombia durante el siglo XIX”, en Sergio Paolo Solano y Roicer Flórez, Infancia de la Nación. Colombia en el primer siglo de la República, Cartagena, Eds. Pluma de Mompox, 2011, pp.23-68.

Dossier: Cuestionando las fuentes de archivos: padrones de población, familias y sociedades coloniales en Iberoamérica, ss. XVIII-XIX 
mestizaje con el nuevo episteme originó unos discursos sobre las relaciones entre el mestizaje-la otredad y la subalternidad.

En una interesante reflexión sobre los elementos de la relación enunciada María Eugenia Chaves ha propuesto que fue durante el siglo XVIII y por efecto del mestizaje y por el interés en la conservación de los privilegios que las elites ligaron la pureza de sangre al origen y al color de las personas. En los dos siglos anteriores de dominio colonial las diferencias que se establecieron en función del color se arraigaban tanto en las experiencias de las relaciones de otredad con pueblos de orígenes diferentes (moros, judíos, indígenas, negros), en la historia de los idiomas ibéricos en los que el término "raza" se asociaba a linaje en un sentido tradicional, al credo religioso y en la experiencia de la guerra contra los musulmanes en la península Ibérica. Esta unión entre las relaciones de otredad, el linaje, la religión y la guerra, dio fundamento a la política de limpieza de sangre. A los mestizos se les controlaba mediante una legislación segregacionista. ${ }^{80}$

Algunos historiadores creen que el empleo de esas categorías aglutinantes era una peculiaridad del Nuevo Reino de Granada, y que estaban ausentes en los padrones de la población de Nueva España, Perú y La Plata. Sin embargo, el resumen del censo del virreinato del Perú de 1790 está presentado en una especie de situación intermedia pues contiene columnas de "españoles", "indios", "mestizos", "mulatos", "negros" y "demás castas de color libres". ${ }^{81}$ Es decir, se siguió diferenciando a los grupos "tradicionales" mientras que a los que eran el resultado de cruces de cruces se les englobó en el rubro genérico de "demás castas de color libres". Y el de Ciudad de México de 1790 es el que más se asemeja al neogranadino, pues clasificó a la población en "españoles", "indios", "mestizos", "gentes de color libres", "gentes de color esclavos". ${ }^{2}$ Es decir, la única diferencia fue colocar aparte a los mestizos, en virtud del enorme peso que tenía ese segmento entre la población de ese virreinato. Las autoridades centrales de esos virreinatos también elaboraron modelos para ser llenados por los empadronadores, como sucedió con los de Nueva España de 1777 y 1790.83 En Nueva España, pese a que se procesaron los resultados del censo de 1777 con el propósito de tener una imagen de conjunto y de rendir

\footnotetext{
80 María E. Chaves, “La creación del 'otro' colonial. Apuntes para un estudio de la diferencia en el proceso de la conquista americana y de la esclavización de los africanos", en María E. Chaves, (editora), Genealogías de la diferencia. Tecnologías de la salvación y representación de los africanos esclavizados en Iberoamérica colonial, Bogotá, Universidad J averiana, 2009, pp.178-243.

81 AGI, Estado, leg.73, exp.40, ff.1r.-2v.

82 AGI, Estado, leg.20, exp.63, ff.1r.-2v.

83 E. Sánchez, Padrón del arzobispado de México 1777, pp.36-37.
}

Dossier: Cuestionando las fuentes de archivos: padrones de población, familias y sociedades coloniales en Iberoamérica, ss. XVIII-XIX 
informes a la Corona, se continuó conservando las singularidades más sobresalientes de las categorías socio-raciales (españoles, castizos, mestizos, indios, mestindios, mulatos, negros, moriscos, chinos, lobos, albinos, coyotes). ${ }^{84}$ Algo parecido sucedió con el resumen del censo de Lima de 1790, en el que se conservaron también las distintas clasificaciones socio-raciales de "españoles, indios, mestizos, negros, mulatos, cuarterones, quinterones, zambos y chinos". ${ }^{55}$ El censo de la ciudad de Veracruz de 1791, realizado por orden del virrey Revillagigedo, también conservó la diversidad de categorías socio-raciales: español, español europeo, moreno libre, moreno esclavo, chino, chino libre, chino esclavo, pardo libre, pardo esclavo, indio libre, indio tributario, indio castizo libre, negra libre, mestizo, mestiza libre, negro esclavo. 86

En el virreinato de La Plata los censos de 1778 de algunos partidos y poblaciones de la provincia de Córdoba también especificaron las distintas condiciones socio-raciales de los habitantes. La transcripción textual y publicación del censo de ese año del partido de Rio Cuatro, en la zona sur de la jurisdicción de la ciudad de Córdoba, sociedad definida como de frontera, muestra que las clasificaciones eran: "español", "mulato esclavo", "mulato libre", "mestiza", "pardo libre", "indio libre", "negro esclavo", "indio", "negro libre", "indio conchabado", "mulato de nación lusitana", "natural de Santa Fe al parecer español", "pasa por español”, "corre por español", "negro libre criollo". Es decir, pese a que la orden señalaba que se indicara "[...] con distinción de españoles, indios, negros y mulatos, y de estos, los que son libres y los que son esclavos [...]", como los padrones los llevaron a cabo vecinos de los respectivos lugares, "[...] para que, como instruidos y peritos de ellos con conocimiento de sus moradores, hagan los respectivos padrones [...]", estos introdujeron categorías que se empleaban en los lugares como mulato, pardo, mestizo. ${ }^{87} \mathrm{En}$ esa área del virreinato de La Plata no se empleaban las clasificaciones de zambos, cuarterones y quinterones. Algunas historiadoras argentinas que han realizado estudios parciales del censo de 1778 en comunicaciones personales nos señalan que en el virreinato de La Plata ese padrón tuvo varios niveles de presentación y que los

\footnotetext{
84 Ver el resumen del censo del arzobispado de Ciudad de México en AGI, Sección Mapas y PlanosVarios, exp.38.

85 AGI, Lima, leg.700, exp.11, f.1v.

86 Archivo Histórico de Veracruz, Padrón de la ciudad de Veracruz, 1791. Agradezco a los colegas Eder Gallegos, Bernardo García e Hilda Flores, el envío de una copia digitalizada de este padrón.

87 María Rosa Carbonari, (editora), El censo de 1778. El partido de Rio Cuatro, Ciudad de Rio Cuatro, Universidad Nacional de Rio Cuatro, 2003, p.8.
}

Dossier: Cuestionando las fuentes de archivos: padrones de población, familias y sociedades coloniales en Iberoamérica, ss. XVIII-XIX 
censos de las poblaciones que ellas conocen registraron una amplia gama de categorías socio-raciales. ${ }^{8}$

En las áreas de las costas marítimas neogranadinas que eran potenciales escenarios de las guerras inter-imperiales, varias razones llevaron a que la condición de libre se constituyera en el factor central para calificar a la población. Por una parte porque estas provincias contaban con las composiciones socio-raciales más complejas de todo el virreinato dado que en el mestizaje intervinieron blancos, indios y negros, dando origen a una gama de categorías que escasamente se conocían en las provincias del interior andino. Para una mentalidad ilustrada que demandaba la contabilización de la población mediante su reducción a cifras estadísticas simples, la gama de denominaciones constituían un problema, ${ }^{89}$ tales como los que se presentaron al organizar las milicias disciplinadas en 1773 , como lo veremos más adelante.

Pero también la clasificación de "libres de todos los colores" obedecía a que permitía ampliar la base social de las gentes con obligaciones para con el Rey, en especial lo que tenía que ver con la defensa militar. La importancia de la libertad también se había resaltado con las reformas poblacionales de mediados del siglo XVIII, que concentró en sitios y parroquias a personas de distintas calidades que tenían en común el no ser esclavo ni indio tributario, y que adquirían la condición política de vecino. Esclavitud y pueblos de indios venían manifestando síntomas de estancamiento y decadencia mientras que los libres alcanzaban un protagonismo significativo en el diseño de las políticas gubernamentales. Para finales de ese siglo la libertad se había convertido en un tema central en la vida de los esclavos y de los indios tributarios, y muchos de estos habían huido de sus pueblos por deudas atrasadas o por no pago del tributo. ${ }^{90} \mathrm{El}$ paso de los pueblos de indios a manos de la Corona también subrayó la importancia de la definición de la libertad como línea

\footnotetext{
88 Comunicaciones personales de las historiadoras argentinas Raquel Gil Montero (Instituto Superior de Estudios Sociales, Conicet-Universidad Nacional de Tucumán), Lorena Rodríguez (Universidad de Buenos Aires) y María Rosa Carbonari (Universidad Nacional de Rio Cuarto). Maria Rosa Carbonari, População, fronteira e família. A região de Río Cuarto no período colonial tardio, Niterói, tesis doctoral-Universidade Federal Fluminense, 2001, p.228. En: http:// goo.gl/AD7yA0.

${ }^{89}$ Marta Herrera, "libres de todos los colores el ordenamiento social en las llanuras del Caribe, siglo XVIII”, en Alberto Abello, (compilador), El Caribe en la nación colombiana. (Memorias), Bogotá, Museo Nacional de Colombia/ Observatorio del Caribe Colombiano, 2006, pp.252, 259.

90 Acerca de los indios fugitivos de sus resguardos ver las matrículas de los tributarios de Ciénaga (provincia de Santa Marta), La Tablada, Guazo y Yatí (provincia de Cartagena), ver: AGN, SC, fondo Caciques e Indios, leg.9, ff.768r.-788v.; leg.28, ff.588r.-604v.; AGN, SC, fondo Residencias-Bolívar, leg.59, ff.432r.-450v.; AGN, SC, fondo Policía, leg.7, ff.645r.-680r.
}

Dossier: Cuestionando las fuentes de archivos: padrones de población, familias y sociedades coloniales en Iberoamérica, ss. XVIII-XIX 
de separación de quienes estaban obligados a tributar. ${ }^{91}$ Además, las poblaciones fundadas a mediados del siglo XVIII en el bajo curso del río Magdalena constituían especies de avanzadas en las guerras contra los indios Chimilas que obstaculizaban la navegación e impedían la colonización de parte de la provincia de Santa Marta situada entre ese río, el pie de monte de la Sierra Nevada de Santa Marta Y el río Cesar. En parte esto explica que desde los poderes centrales del virreinato de la Nueva Granada se le haya dado preeminencia a la categoría de "libres de todos los colores".

\section{Contrastes entre padrones locales y resúmenes provinciales}

Al final de algunos censos de las localidades y partidos se anotaron unos resúmenes que variaron acorde con la interpretación que dio cada empadronador a las exigencias de las autoridades provinciales y centrales del virreinato. Los padrones de los barrios Santo Toribio, San Sebastián, La Merced y Getsemaní de Cartagena incluyeron columnas sobre "personas eclesiásticas, vecinos, almas libres, esclavos y total". ${ }^{2}$ El de la población de El Retiro (provincia de Cartagena) se presentó por gé neros, edades y esclavos. ${ }^{93} \mathrm{El}$ de Tacamocho solo se presentó por géneros..$^{94}$ Los de Santiago, San Fernando, San Sebastián y Portobelo no presentaron resúmenes. ${ }^{95} \mathrm{El}$ de la ciudad de Riohacha cruzó información sobre el estado civil (casado, soltero, viudo y párvulo), con las categorías de "blancos", "negros", "zambos", "pardos", "indios" y "esclavos". ${ }^{96} \mathrm{Y}$ el extracto de la provincia homónima marca una diferencia con los demás resúmenes que se elaboraron de 1778 en adelante al contener columnas sobre "blancos", "pardos", "zambos", "negros", "esclavos", "indios" y "mestizos". No aparece en este resumen la columna de "libres de todos los colores". ${ }^{97}$ No necesariamente por estar cerca o lejos de los centros urbanos de poder,

\footnotetext{
91 Marta Herrera, Ordenar para controlar. Ordenamiento espacial y control político en las llanuras del Caribe y en los Andes centrales neogranadinos, siglo XVIII, Bogotá, Instituto Colombiano de Antropología e Historia/ Academia Colombiana de Historia, 2002, pp.171-198.

92 AGN, SC, Miscelánea, leg.41, f.1004r.; leg.44, f.958r.; AGN, SC, CR-CVD, leg.8, ff.134v., 164v.

93 AGN, SC, Poblaciones-Varias, leg.4, f.537r.

94 AGN, SC, Miscelánea, leg.44, f.959r.

95 AGN, SC, Miscelánea, leg.3, ff.30r.-46v.

96 AGN, SC, CR-CVD, leg.6, f.537v.

97 AGN, SC, CR-CVD, leg.8, f.581r.
}

Dossier: Cuestionando las fuentes de archivos: padrones de población, familias y sociedades coloniales en Iberoamérica, ss. XVIII-XIX 
los censos de las poblaciones se atenían a las exigencias de las autoridades centrales, pues los de algunos barrios de Cartagena omitieron exigencias establecidas en la real orden de 1776, mientras que los del área de influencia de Mompox si se acogieron a estas.

El resumen general y los censos de los sitios y parroquias de libres del Partido de Tierradentro presentan las columnas de "eclesiásticos, vecinos, almas, naturales, esclavos y total de almas". ${ }^{98}$ Pero los de los pueblos de indios de Galapa, Malambo, Tubará, Piojó, Media Granada y Usiacurí colocaron en columnas diferentes a "vecinos" y "libres", 99 lo que llama la atención pues en el contexto de un pueblo de indios un vecino era una persona libre, tal como se registró en los padrones de los pueblos de indios de Turbaco y Turbana, en las inmediaciones de Cartagena. ${ }^{100}$

Aun en los casos de reformas de población en la provincia de Cartagena del decenio de 1740 también se estableció esa relación, como sucedió con el traslado de los indios de Baranoa al pueblo de Galapa y la agregación de los vecinos libres de los alrededores a la primera para ser erigida en parroquia. ${ }^{101}$ Los indios se referían a los vecinos por la condición de "libres", como sucedió en 1798 cuando los del pueblo de San Pedro de la Tablada (jurisdicción de Simití, provincia de Cartagena), pidieron las autoridades que sacaran a aquellos, o que de quedarse se sujetaran a la autoridad del cabo de libres o del alcalde indígena y pagaran el canon de arrendamiento de las tierras, y que se evitase que las autoridades de Simití y de Morales intentaran tener jurisdicción sobre la vida interna del pueblo. ${ }^{102}$

Aunque a que las autoridades virreinales insistieron en que se les enviasen los resúmenes del censo de 1777, la falta de uniformidad en los padrones imposibilitó la realización del cuadro sumario general del virreinato correspondiente a ese año. Años después, en 1789, el virrey Antonio Caballero y Góngora se refería al fracaso de los esfuerzos que había hecho su antecesor en ese cargo, el virrey Manuel Antonio Flórez, para contar con un resumen de los padrones de 1777 y 1778 para todo el Nuevo Reino de Granada. En su Relación de Mando presentada en aquel año anotó:

98 AGN, SC, CR-CVD, leg.8, ff.198r., 98r.-236v.

${ }^{99}$ AGN, SC, CR-CVD, leg. 8, ff.169v., 177v., 187r., 197r., 206r., 211v.

100 AGN, SC, CR-CVD, leg. 8, ff.781v.-790r.

101 AGN, EOR-CP, Serie 22, Caja 12, ff.231r.-237v.; J osé A. Blanco, Obras completas, tomo II, Barranquilla, Universidad del Norte, 2014, pp.107-141.

102 AGN, SC, Policía, leg.11, ff.396r.-415v.; AGN, SC, Miscelánea, leg.131, ff.955r.-957v.

Dossier: Cuestionando las fuentes de archivos: padrones de población, familias y sociedades coloniales en Iberoamérica, ss. XVIII-XIX 
Posteriormente [se refería a un cálculo de la población realizado en 1770 por Francisco Moreno y Escandón] en cumplimiento de Real Orden [la de noviembre 10 de 1776] se empeñó nuestro antecesor don Manuel de Flórez en juntar todos los padrones particulares para la formación de uno general. A cuyo efecto, hizo formar modelos que circularon a todos los gobernadores y corregidores, para que viniesen uniformes, y no con la confusión con que habían empezado a hacer. Pero jamás pudo juntas todos los de un año en el tiempo de su gobierno. ${ }^{103}$

En las tablas 1 y 2 puede verse de forma muy resumida la diversidad de categorías socio-raciales empleadas en 43 poblaciones neogranadinas, construidas con base en los padrones de 1777. Con esa muestra podrán imaginar lo difícil que hubiese sido realizar un resumen para todo el virreinato que acogiera las distintas categorías. Por eso el censo de ese año puede tomarse como un fracaso, del que se aprendió que era lo que no le interesaba a la administración central del virreinato. Y esto sucedió a pesar de los celos de algunos altos funcionarios del virreinato como Francisco Moreno y Escandón, quien en 1778 visitó parte de las poblaciones de los Andes centrales neogranadino y exigió a las autoridades parroquiales la presentación de los padrones de habitantes levantados el año inmediatamente anterior. ${ }^{104}$

En 1780 J osé Manuel Campusano y Lanz, gobernador de la provincia de Tunja, explicó al virrey Flórez los problemas que se presentaron con los censos, y por qué no envió los resúmenes de 1777 y 1778: "Aunque se hallan en mi poder los padrones de los años de 77 y 78, a excepción del de Pamplona y sus distrito, omito su remesa por ser formados en los términos anteriormente prevenidos, que realmente presentan grave confusión [...]" ${ }^{105}$ En comunicación dirigida al Cabildo de Santa Fe de Bogotá el virrey expresó los problemas que se presentaron en la realización de los padrones de 1777: "Bien entendido que habrá de comenzarse por el del presente de 1778 porque se podrá practicar con más regularidad y arreglo, y conforme al espíritu de la citada real orden". ${ }^{106}$ Para esto emplearon el planecillo que diseñó ese virrey a comienzos de ese año, "[...] para que sirva de pauta, y no halla otra cosa que hacer, sino llenar las casillas que van designadas en él con las sumas que correspondan a cada estado, clase y casta [...]". ${ }^{107}$ En consecuencia, fue

103 AGI, Estado, leg.54, ff.89r.-v.

104 AGN, SC, Visitas-Santander, leg.4, ff.940r-946r.; leg.8, f.908r.

105 AGN, SC, Miscelánea, leg.82, f.12v.

106 AGN, SC, Fondo Virreyes, leg.1, f.300r.

107 AGN, SC, CR-CVD, leg.6, f.310r. yv.

Dossier: Cuestionando las fuentes de archivos: padrones de población, familias y sociedades coloniales en Iberoamérica, ss. XVIII-XIX 
de ahí en adelante cuando las autoridades de algunas provincias neogranadinas presentaron al gobierno central del virreinato de la Nueva Granada unas síntesis en las que agruparon a los habitantes de las poblaciones en cuatro grandes categorías: "estado eclesiástico", "blancos", "indios", "libres de varios colores" y "esclavos de varios colores". 108

Tabla 1: Categorías socio-raciales en padrones de provincias Caribe neogranadino, 1777

\begin{tabular}{|c|c|c|c|c|c|c|c|c|c|c|c|c|c|c|}
\hline Yo Calidades & 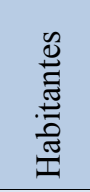 & 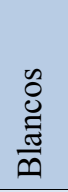 & 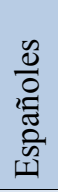 & $\begin{array}{l}\text { o } \\
\text { ț } \\
0 \\
\text { Z }\end{array}$ & $\frac{n}{\stackrel{0}{c}}$ & $\begin{array}{l}\text { ̊ } \\
\text { हี } \\
\text { స్ } \\
\text { N }\end{array}$ & $\frac{0}{0}$ & 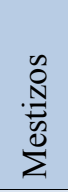 & 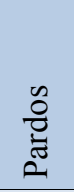 & 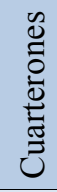 & 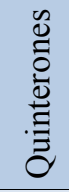 & 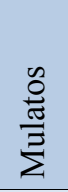 & 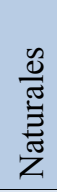 & 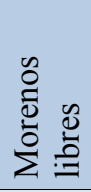 \\
\hline \multicolumn{15}{|c|}{ Provincia de Cartagena } \\
\hline Cartagena $^{@}$ & 10.470 & 6,8 & -- & 28,0 & 0,3 & 2,8 & --- & 0,4 & 12,0 & 1,7 & 0,02 & 11,2 & --- & -- \\
\hline Tacamocho & 899 & 2,1 & --- & 0,4 & --- & 30,8 & 8,4 & 8,2 & 40,4 & 4,7 & 0,8 & --- & --- & -- \\
\hline El Retiro & 1201 & 7,0 & --- & 11,1 & --- & 23,0 & 8,8 & 22,1 & 19,4 & 6,5 & 1,2 & --- & --- & --- \\
\hline Santiago & 364 & 0,3 & 1,6 & --- & --- & 10,2 & --- & 30,5 & 48,9 & 6,3 & --- & 2,2 & --- & -- \\
\hline$* *$ & 1023 & 6,3 & 1,6 & 2,6 & 0,5 & 39,8 & --- & 29,5 & 1,1 & 4,9 & --- & 7,3 & 7,0 & 0,4 \\
\hline Tacasaluma & 619 & 2,1 & --- & -- & --- & 36,8 & 11,5 & 13,4 & 28,0 & 2,1 & 0,6 & -- & -- & 5,8 \\
\hline Tacaloa & 522 & 11,9 & --- & 4,2 & 1,1 & 29,7 & 5,7 & 22,8 & 4,9 & 1,5 & -- & 18,2 & -- & -- \\
\hline San Sebastián & 844 & 4,9 & --- & 3,7 & 0,2 & 19,2 & 15,1 & 25,3 & 28,4 & 2,5 & 0,2 & 0,6 & --- & --- \\
\hline San Fernando & 325 & 22,5 & --- & 0,9 & --- & 1,2 & 2,2 & 57,8 & 10,2 & 5,2 & --- & --- & -- & -- \\
\hline \multicolumn{15}{|c|}{ Provincia de Riohacha } \\
\hline Riohacha & 1789 & 11,5 & --- & 22,4 & 0,7 & 17,3 & --- & --- & 44,6 & --- & --- & -- & --- & 3,7 \\
\hline Moreno & 857 & 1,3 & --- & $8,3^{*}$ & --- & 24,6 & -- & -- & 63,6 & -- & --- & --- & -- & 2,0 \\
\hline Villa de Pedraza & 304 & 6,3 & --- & $6,9 *$ & --- & 27,3 & --- & 0,3 & 57,2 & --- & --- & --- & --- & 2,0 \\
\hline Camarones & 111 & --- & --- & $1,8^{*}$ & --- & 27,9 & -- & -- & 64,9 & -- & --- & --- & -- & 5,4 \\
\hline $\begin{array}{l}\text { Pueblo de } \\
\text { Boronata }\end{array}$ & 201 & --- & --- & $6,0^{*}$ & 6,0 & 40,8 & --- & 6,5 & 27,9 & --- & --- & --- & --- & 12,9 \\
\hline Sinamayca & 346 & 46,8 & --- & -- & 3,5 & 4,3 & -- & 1,4 & 43,6 & --- & --- & -- & -- & 0,3 \\
\hline Bahía Honda & 118 & 8,5 & --- & -- & --- & 6,8 & -- & -- & 65,3 & -- & --- & --- & -- & 19,4 \\
\hline Sabana del Valle & 54 & 38,9 & --- & --- & --- & 13,0 & --- & 14,8 & 29,6 & -- & --- & --- & --- & -- \\
\hline \multicolumn{15}{|c|}{ Provincia de Portobelo } \\
\hline Portobelo & 1844 & 4,9 & --- & 1,1 & 1,2 & 11,0 & --- & 0,8 & 23,0 & 3,6 & 0,9 & -- & 0,9 & 52,4 \\
\hline
\end{tabular}

Fuentes: AGN, SC, Miscelánea, leg.3, ff.30r.-46v.; leg.39, ff.1004r.-1078v.; leg.44, ff.945r.-958v.; ff.959r.-973r.; AGN, SC, Poblaciones-Varias, leg.4, ff.450r.-459v., 516r.-537v.; leg.10, ff.498r.-538v.; AGN, SC, CR-CVD, leg.6, ff.581r.; 222r.-231v.; leg.8, ff.75r.-134v., 132r.-164v.; ff.498r.-525v.; 879r.885v. *Esclavos. **Por no tener encabezamiento no ha sido posible establecer la población a que corresponde este padrón. @ Del total de habitantes solo se dio la información de la condición socio-racial del 47,8\%. AGN, SC, Miscelánea, leg.31, ff.148r.-154v. y leg. 41, ff.1014r.-1015v.; AGN, SC, CRCVD, leg.6, ff.259r.-260v. y 615r.-619v.; Censos Varios, leg.VIII, ff.75r.-134v. M. Aguilera y A. Meisel, Tres siglos de historia demográfica de Cartagena de Indias, p.35.

108 En el caso de la provincia de Cartagena contamos con el de 1778 fechado el 26 de noviembre de ese año. AGN, Sección Mapas y Planos, Mapoteca 7, ref:1353, f.21r. Y los de 1779 y 1780 datados el 31 de diciembre de cada año. AGN, SCS., EOR-CP, Serie 22, Caja 12, ff.11r.-12v. Otros resúmenes en AGN, SCs., EOR-CP, Serie 22, Caja 12, ff.4r.-6v.; AGN, SC, CR-CVD, leg.6, ff.364r.-366v.

Dossier: Cuestionando las fuentes de archivos: padrones de población, familias y sociedades coloniales en Iberoamérica, ss. XVIII-XIX 
Tabla 2: Categorías socio-raciales en padrones de los Andes centrales neogranadino, 1777-1778

\begin{tabular}{|c|c|}
\hline Parroquias y pueblos & Categorías \\
\hline \multicolumn{2}{|r|}{ Provincia de Pamplona } \\
\hline Parroquia de Capitanejo & "blancos de distinción", "cuarterones", "mestizos", "indios", "mulatos". \\
\hline Parroquia de Tequia & $\begin{array}{l}\text { "blancos principales", "indios", "mestizos", "pardos", "mulatos" y "escla- } \\
\text { vos". }\end{array}$ \\
\hline Parroquia Macaravita & "gente noble", "mestizos" y "gente de color pardo". \\
\hline Parroquia de San Miguel de Oiba & 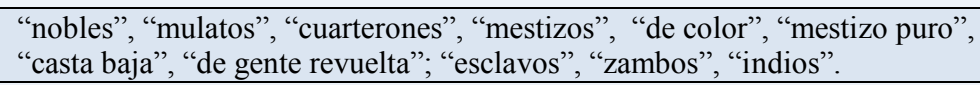 \\
\hline Parroquia de Molagavita & "blancos", "mestizos", "indios"y "mulatos". \\
\hline Parroquia Llano de Enciso & "blancos limpios de sangre", "mestizos", "mulatos". \\
\hline Parroquia de Poyma & "nobles", "blancos", "mestizos", "pardos" e “indios". \\
\hline Ciudad de Salazar de las Palmas (1777) & $\begin{array}{l}\text { "personas de primera plana que llamamos caballeros, que han gobernado y } \\
\text { pueden gobernar esta ciudad de Salazar de las Palmas"; "personas blancas } \\
\text { limpias"; "1 } 1^{a} \text { clase", " } 2^{\text {a }} \text { clase", " } 3^{\text {a }} \text { clase"; "casta de mestizos"; "casta de } \\
\text { mulatos, negros y zambos". }\end{array}$ \\
\hline Parroquia de San Cayetano (1777) & $\begin{array}{l}\text { "gente noble", "gente blanca del común", "indios y mestizos", "mulatos y } \\
\text { negros", "esclavos", "gente parda de comunidad". }\end{array}$ \\
\hline Parroquia de Santiago (1777) & $\begin{array}{l}\text { "gente noble", "gente blanca del común", "indios y mestizos", "mulatos y } \\
\text { negros", "esclavos", "gente parda de comunidad". }\end{array}$ \\
\hline Ciudad de Salazar de las Palmas (1778) & Nobles, esclavos, negros, mulatos, blancos, indios libres, $2^{\mathrm{a}}$ clase, sirvientes. \\
\hline Parroquia de San Cayetano (1778) & “Nobles”, “2 clase”, “indios”, “mulatos”, “esclavos”. \\
\hline Parroquia de Santiago (1778) & "Nobles", "2a clase”, “indios", "mulatos”, “esclavos”, “indios”. \\
\hline Villa de El Socorro (1778) & Nobles, blancos, mestizos, indios y mulatos. \\
\hline \multicolumn{2}{|r|}{ Provincia de Tunja } \\
\hline Parroquia de Suatá & "blancos", "mestizos", "indios" y "mulatos". \\
\hline Parroquia de Santa Rosa de Viterbo & $\begin{array}{l}\text { Solo se señaló la calidad de los "principales de la parroquia". En sus agrega- } \\
\text { ciones aparecen "principales", "mulatos libres" e "indios forajidos". }\end{array}$ \\
\hline Parroquia de Cerinza & $\begin{array}{l}\text { "clase de blancos", "clase de mestizos", "clase de mulatos", "Clase de in- } \\
\text { dios". }\end{array}$ \\
\hline Parroquia de Sátiva & "blancos", "indios" y "mulatos". \\
\hline Parroquia de la Sinselada & Nobles, esclavos, naturales, pardos. \\
\hline Pueblo de Firavitoba & “caballeros", "blancos", “mestizos” y "pardos". \\
\hline Pueblo de Iza & “caballeros", "blancos", "mestizos" y "pardos". \\
\hline Pueblo de Nobsa & “caballeros", "blancos", “mestizos” y "pardos". \\
\hline Pueblo de Chámeza & “caballeros", "blancos", "mestizos" y "pardos". \\
\hline Pueblo de Monguí & “caballeros", "blancos", “mestizos" y "pardos". \\
\hline Pueblo de Tibasosa & "caballeros", "blancos", “mestizos" y "pardos". \\
\hline Pueblo de Tota & "clase de blancos" y "clase de mestizos". \\
\hline Pueblo Viejo & Solo señaló la calidad a los "blancos". \\
\hline Pueblo de Sogamoso & A pocos se les agregó "noble", "mestizo", "mulato", "liberto". \\
\hline Pueblo de Cuítiva & "clase de blancos", "mestizos", "indios", "mulatos". \\
\hline
\end{tabular}

Fuentes: AGN, SC, CR-CVD, leg.6, ff.376r.-385v., 453r.-470v. y 714r.-716v.; leg.8, ff.366r.-374v.; 420r.448v., 578r.-590v., 652r.-664v., 669r.-674v., 681r.-702v., 732r.-759v., 846r.-878v., 886r.904v.; AGN, SC, Miscelánea, leg.41, ff.993r.-994v., 995r.-998v., 999r.-1003v.; leg.44, ff.924r.-943v.; AGN, SC, Visitas-Santander, leg.2, ff.997r.-1015v.; leg.4, f.948v. 
El levantamiento popular de los Comuneros en 1781 impidió realizar censos entre 1881 y 1783. Se realizó uno en 1784 y luego otro en 1788. En 1789 Caballero y Góngora, después de informar las dificultades que afrontó su antecesor para realizar un resumen para todo el virreinato, anotó: “[...] ni yo he tenido por conveniente estrechar en este particular, porque después de las inquietudes del Reino, la malicia de algunos y la ignorancia de los más, hizo extender la voz de que esta operación era dirigida a un nuevo impuesto, con lo que los padres ocultaban la mitad de su familia, sino podían esconderse en los montes mientras el empadronamiento". ${ }^{109}$

En fin, debido a tantas dificultades en la secretaría del virreinato se fueron acumulando padrones de localidades y resúmenes provinciales de los años de 1777 en adelante sin que prestaran utilidad alguna. En 1788 el virrey Antonio Caballero y Góngora ordenó integrar un resumen con base en los informes provinciales de 1778, 1779 y 1780. El ensamble se realizaría en torno a los resúmenes del primer año mencionado dado que era los más numerosos, pues en la secretaría del virreinato reposaban los resúmenes del padrón de 1778 de las provincias de Santa Fe de Bogotá, Guayaquil, Cartagena, Santa Marta, Riohacha, Portobelo, Panamá, Veragua, Alhange, Darién, Antioquia, Mariquita, Girón, Los Llanos, J aen, Neiva, Cuenca, Loja, Pamplona, Chocó y Nóvita. También estaba los resúmenes de 1779 de las provincias de Quito, Popayán y Tunja; los correspondientes a 1780 de la provincia de Mainas y de la ciudad de Salazar de las Palmas (esta dependía directamente de Santa Fe de Bogotá); y los de 1781 correspondientes a Quijos y Mainas. ${ }^{110}$

En su Relación de Mando el virrey Caballero y Góngora escribió que había ordenado "[...] que de todos los padrones particulares que había en la secretaría se formase uno general, aunque no fuesen todos de un solo año, y en efecto se ha conseguido, fijándose en cuanto ha sido posible en el de 78, de que son más". 111

Así que los resúmenes que usualmente emplean los historiadores para analizar la configuración social de todo el virreinato fueron productos de unos ensambles, y de una reducción de una multitud de categorías socio-raciales que fueron integradas bajo el rubro de "libres de todos los colores". Esto expresaba la presencia de una mentalidad ilustrada, la que a partir de 1773 en adelante se esforzó en organizar y restructurar las milicias disciplinadas con base en unos criterios insti-

\footnotetext{
109 AGI, Estado, leg.54, ff.89r.-v.

110 AGN, SC, MM, leg.141, ff.140r.-147v.

111 AGI, Estado, leg.54, ff.89r.-v. El resumen hecho en 1788 relativo a los años de 1778-1780 puede verse en Archivo Histórico Nacional (Madrid), Diversos-Colecciones, leg.32, exp.35. También se puede consultar en AGI, Estado, leg.54, ff.228r.-229r.
}

Dossier: Cuestionando las fuentes de archivos: padrones de población, familias y sociedades coloniales en Iberoamérica, ss. XVIII-XIX 
tucionales que les permitiera menguar el poder de las elites provinciales y locales y ganar aliados entre los sectores subalternos mediante las asignaciones de nuevas identidades políticas a los habitantes comunes y corrientes, las que les permitieron una relaciones con las instituciones distintas a las que usualmente habían tenido.

Tabla 3: Relación entre libres (blancos y gentes de distintas condiciones), esclavos y no libres (esclavos e indios) en algunas provincias neogranadinas, 1778-1780

\begin{tabular}{|l|r|r|r|r|r|r|r||}
\hline \multicolumn{1}{|c|}{ Provincias } & Censos & $\begin{array}{c}\text { Población } \\
\text { total }\end{array}$ & Libres & Esclavos & Indios & $\begin{array}{c}\text { Libres- } \\
\text { Esclavos }\end{array}$ & $\begin{array}{c}\text { Libres- } \\
\text { no } \\
\text { libres }\end{array}$ \\
\hline Tunja & 1780 & 258.617 & 216.384 & 6.047 & 36.186 & $36: 1$ & $5: 1$ \\
\hline Santa Fe de Bogotá & 1779 & 92.042 & 59.431 & 1.166 & 31.475 & $33: 1$ & $2: 1$ \\
\hline Neiva & 1778 & 26.442 & 21.708 & 884 & 3.850 & $25: 1$ & $5: 1$ \\
\hline Veragua & 1778 & 20.207 & 12.081 & 520 & 7.606 & $23: 1$ & $2: 1$ \\
\hline Cartagena & 1779 & 118.685 & 89.073 & 9.103 & 20.509 & $10: 1$ & $3: 1$ \\
\hline Mariquita & 1778 & 47.138 & 37.919 & 4.143 & 5.076 & $9: 1$ & $4: 1$ \\
\hline Girón & 1779 & 6.791 & 5.729 & 852 & 210 & $7: 1$ & $5: 1$ \\
\hline Riohacha & 1778 & 3.966 & 2.865 & 469 & 632 & $6: 1$ & $3: 1$ \\
\hline Popayán & 1780 & 68.875 & 36.338 & 16.445 & 16.092 & $2: 1$ & $1: 1$ \\
\hline Antioquia & 1778 & 420.656 & 244.683 & 137.254 & 38.719 & $2: 1$ & $1: 1$ \\
\hline Chocó & 1778 & 14.664 & 3.432 & 5.756 & 5.476 & $1: 1$ & $0,3: 1$ \\
\hline Nueva Granada & 1788 & 1.279 .440 & 751.178 & 69.529 & 458.736 & $11: 1$ & $1: 1$ \\
\hline \hline
\end{tabular}

Fuentes: AGN, SC, CVD, leg.6, ff.261r., 360r., 366r., 442r.; leg.8, f.415r.; AGN, Sección Mapas y Planos, Mapoteca 4, ref.:698-A; AGN, SCs., EOR, Caja 12, ff.5r., 6r., 7r., 11r., 15r., 18r.

Pues bien, al comparar los resúmenes del censo de 1778 de las provincias de Riohacha y de Cartagena (tabla 3) y los padrones particulares de 1777 de algunas sus poblaciones (tabla 1), se evidencian unos contrastes que obligan a preguntarse en qué medida unos y otros reflejaban la configuración social de estas. ${ }^{112}$ En efecto, según el resumen de 1778 la provincia de Riohacha tenía 3966 habitantes, y de esta cifra el 63,4\% eran "libres de todos los colores". ${ }^{113}$ Sin embargo, los datos desagregados del censo del año anterior muestran que entre esos "libres de todos los colores" un $49,4 \%$ correspondía a pardos, $19,8 \%$ a zambos, $3,8 \%$ a negros libres y $0,7 \%$

112 Manuel Miño ha llamado la atención sobre los contrastes entre los resúmenes generales y los particulares de las poblaciones en el censo de Ciudad de México de 1790. "Para la historia social. Tablas de edad, estado marital y grupos raciales de la población de la Ciudad de México, 1790 (13 cuarteles)”, en Historia Mexicana vol.LVII, n. ${ }^{\circ 3}$, México D. F., El Colegio de México, 2008, pp.911944.

113 AGN, SC, CR-CVD, leg.6, f.360r.

Dossier: Cuestionando las fuentes de archivos: padrones de población, familias y sociedades coloniales en Iberoamérica, ss. XVIII-XIX 
a mestizos. ${ }^{114}$ Y esto tenía profundas implicaciones pues el registro de los habitantes solo por el color dejaba de lado, como lo ha mostrado J osé Polo Acuña, que la alta Guajira era una sociedad matrifocal, y en consecuencia la mayoría de las gentes de color estaban insertas en la sociedad y en la cultura indígena. ${ }^{115}$

De igual forma, las poblaciones de la provincia de Cartagena que hemos registrado en la tabla 1 contaban con una población agregada de 5797 personas. Según el resumen de 1778 de esa cifra el 92,7\% eran "libres de todos los colores"116. Pero una mirada más detallada por localidades muestra las diferencias de las calidades entre los habitantes de cada población ${ }^{117}$. A manera de ilustración anotemos que la parroquia de San Sebastián tenía 844 habitantes, de los que el 95,5\% aparecen catalogados en el cuadro resumen de 1778 como "libres de varios colores". Empero, en el padrón del año anterior levantando casa por casa y persona por persona, lo que aparecen son "blancos", "negros", "indios", "zambos", "cholos”, "mestizos", "pardos", "cuarterones", "quinterones" y "mulatos”, en las distribuciones porcentuales señaladas en dicha tabla.

Y en correspondencia con el predominio de los sectores que aparecen en el mencionado censo, en el listado de 1780 de la compañía de milicianos de "todos los colores" de esta población integrada por 101 hombres, el 56,4\% eran mestizos, $16,8 \%$ pardos, $12,9 \%$ zambos, $8,9 \%$ cholos, $4,0 \%$ cuarterones, y el 1,0\% restante eran quinterones. ${ }^{118}$ Algo similar acontecía en la parroquia de Tacamocho, la que en el mencionado resumen aparece con un 98,8\% de "libres de todos los colores". Empero en el padrón de esa población aparece gente registrada bajo las categorías señaladas en la tabla 2, exceptuando a "indios" y "mulatos". Y la constitución de la compañía de los 94 milicianos de "todos los colores" de esta población, refleja de manera exacta esa composición social, pues el 58,5\% eran "zambos", el 23,4\% “mestizos", el 10,6\% "pardos”, el 4,3\% "morenos”, y el 3,2\% "blancos”. ${ }^{119}$ Y en ese

114 AGN, SC, CR-CVD, leg.6, f.581r.

115 J osé Polo Acuña, Indígenas, poderes y mediaciones en la Guajira en la transición de la Colonia a la República (1750-1850), Bogotá, Universidad de los Andes, 2012, pp.231-271.

\footnotetext{
116 AGN, Sección Mapas y Planos, Mapoteca 7, ref:1353, f.21r.

117 AGN, Sección Mapas y Planos, Mapoteca 7, ref:1353, f.21r.

118 AGN, SC, MM, leg.14, ff.209r.-210r.

119 AGN, SC, MM, leg.14, ff.175r.-176v.
}

Dossier: Cuestionando las fuentes de archivos: padrones de población, familias y sociedades coloniales en Iberoamérica, ss. XVIII-XIX 
orden de ideas podemos seguir con las otras poblaciones que integran esa tabla, como también en los listados de milicianos de 1780.120

\section{Padrones locales, poder y clasificaciones socio-raciales}

Los padrones que dieron detalles sobre los habitantes de las poblaciones pueden asumirse como parte de un discurso mucho más amplio y solo perceptible por medio de diversas fuentes de archivos que dan pistas sobre las características de la sociedad y de sus integrantes. Las calificaciones sociales tenían distintos significados de acuerdo al lugar donde se empleaba y de quienes las utilizaban y en qué contexto se usaban, como lo muestran los padrones de algunas poblaciones del oriente andino neogranadino y de las provincias caribeñas de Cartagena, Riohacha y Portobelo. En cambio otros hicieron caso omiso de esas demandas. Pero por encima de cada caso lo importante es lo que puede decirnos tantos las omisiones como las afirmaciones.

En el primer caso se encuentra el censo de la ciudad de Salazar de las Palmas (provincia de Pamplona), el que llama la atención por la forma como se organizó y por las expresiones del empadronador sobre los cruces entre categorías de personas de distintas condiciones sociales (ver tabla 2). Téngase presente que esta ciudad tenía unas características particulares pues su población vivía dispersa en el campo, sus notables eran propietarios de tierras, y, según el informe del visitador don Francisco Moreno y Escandón rendido en 1778, aquella carecía de lo más mínimo para ser considerada una ciudad. Enclavada entre las ciudades de Pamplona y Ocaña, era autónoma en el manejo de sus asuntos públicos y ello contribuía a la desorganización de la administración pues dependía directamente de las autoridades centrales del virreinato ${ }^{121}$. La dispersión de la población en un dilatado territorio dificultaba llevar a cabo el censo de la población, por lo que el de 1777 lo realizó uno de sus alcaldes ordinario de primera nominación, “[...] arreglado al padrón que el Señor Cura y Vicario [...] tiene presentado [...]”.122

Por seguir a pie juntillas el padrón eclesiástico que con base en los libros de bautismos, matrimonios y defunciones estaba organizado teniendo presente las

120 AGN, SC, MM, leg.14, ff.51r.-52v.; 169r.-174v.; 175r.-176v.; 177r.-210v.; leg.15, ff.939r.-940v.; 953r.-955v.; leg.17, ff.204r.-206v.; 260r.-310v.; leg.21, ff.373r.-380v.; leg.48, ff.678r.-680v.

121 AGN, SC, Visitas-Santander, leg.2, ff.989r.-1014v.

122 AGN, SC, CR-CVD, leg.6, f.453r.

Dossier: Cuestionando las fuentes de archivos: padrones de población, familias y sociedades coloniales en Iberoamérica, ss. XVIII-XIX 
características de las personas de acuerdo a sus ascendientes, enlaces matrimoniales y descendientes, se trata del censo más "complicado" de los que hemos consultado. Al parecer allí los libros de la iglesia se habían llevado en celoso orden, especificando las características sociales de los feligreses que contraían matrimonios, los bautizados y los difuntos, lo que se reflejó en el padrón de la población. Su encabezamiento reza: "Padrón de las personas de primera plana y excepción que son los capitulares que llamamos caballeros, que han gobernado y pueden gobernar esta ciudad de Salazar de las Palmas, y cualquier otra en que se avecindaren según su limpio nacimiento y mérito, tanto criollos cono forasteros radicados en ella. Que se forma con distinción de las demás calidades inferiores y castas de gentes [...].123

Los habitantes estaban clasificados en " 1 a clase" en la que se agrupaban a los blancos "caballeros" que poseían los distintivos de "don" y "doña", que ocupaban cargos en la república, ${ }^{124}$ es decir, a quienes vinculaban esa calidad y la prestancia con la riqueza. También agrupaba a blancos que no poseían las anteriores condiciones de ejercer cargos públicos y que carecían de la condición del "don" y "doña". Sobre los "caballeros" en 1802, a propósito de la oposición de algunos notables para que determinados sitios no fueran erigidos en parroquias, el gobernador de la provincia de Girón se expresó de la siguiente forma: "Los que se llaman caballeros, pobres por su constitución [temperamento], aunque dueños de muchas tierras, que la mayor parte tienen sin cultivos o desiertas, acomodados a esta vida silvestre, no aspiran a que se funden poblaciones [pues] la inmediación a los jueces y curas les haría decaer de aquel predominio que tienen adquirido sobre los pobres circunvecinos". 125

De manera puntillosa este padrón discrimina a las parejas de casados de acuerdo a las clases a que pertenecieran los cónyuges. Personas de la $1^{\text {a }}$ clase estaban casadas con otras pertenecientes a la $2^{\underline{a}}$ y $3^{\text {a }}$ clase, y así se les registró en el listado de aquellas. Los hijos de estos matrimonios se registraban en la condición del cónyuge de menor estatus. También, siguiendo una característica muy propia de los libros de iglesias, se anotaba cuando la pertenencia a la 1a clase estaba en entredicho, como sucedió con una familia de la que registró que pertenecía "según

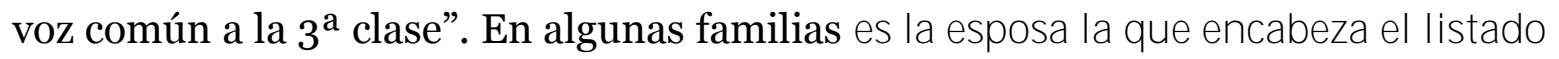
de miembros y luego sigue el esposo de quien se dice "el que consta en la $2^{\mathrm{a}}$ ".

123 AGN, SC, CR-CVD, leg.6, f.453r.

124 AGN, SC, CR-CVD, leg.6, f.453r.

125 AGN, SC, Poblaciones-Santander, leg.2, f.430r.

Dossier: Cuestionando las fuentes de archivos: padrones de población, familias y sociedades coloniales en Iberoamérica, ss. XVIII-XIX 
Luego del listado de la " 1 a clase" el empadronador escribió: "Padrón de todas las personas blancas limpias, que comprende esta ciudad de Salazar, desde los mayores hasta los párvulos, con separación de nobles, mestizos y mulatos", lo que es de suponer que se refería a los de $2^{\text {a }}$ clase. A los blancos agrupados en esta clase no se les anotó el distintivo de "don"; a algunos se les anotó "este es [de] la $3^{\mathrm{a}}$ clase", pero como estaba casado con una mujer de $2^{\text {a }}$, aparece registrado en la $2^{\text {a }}$. A otros se les registró que sus esposas e hijos estaban en la $3^{\text {a }}$ o en la $4^{\text {a }}$ clase.

Sigue luego con "Padrón de todas las personas desde los mayores hasta los párvulos, de la casta de mestizos, que comprende esta jurisdicción o ciudad de Salazar, con distinción y separación de mulatos, nobles y blancos limpios”. Termina con el "Padrón de la casta de mulatos, negros y zambos, desde los mayores hasta los menores o párvulos, que comprende esta jurisdicción o ciudad de Salazar, con distinción y separación de los nobles, de los blancos limpios y de los mestizos". ${ }^{126}$

El padrón del año siguiente (1778) simplificó la lectura del orden social y de sus categorías. En el aparecen "nobles, blancos, $2^{\mathrm{a}}$ clase, indios, mestizos, mulatos, esclavos". No se registraron los cruces de una clase con otra como si se había hecho en el año anterior. Desaparecieron la $1^{\underline{a}}$ y la $3^{\underline{a}}$ clase. ${ }^{127}$ En esto debió influir la presencia de don Francisco Moreno y Escandón, quien por ese entonces se hallaba visitando los pueblos, parroquias, villas y ciudades de los Andes centrales. Para los propósitos de las autoridades centrales del virreinato esos "detalles" eran de interés local y de jurisdicción judicial.

De los censos de 1777 que conocemos el de Salazar de las Palmas fue el que más se ajustó a un padrón eclesiástico, cruzando factores como las calidades socioraciales de las personas, la prestancia social, la riqueza y el desempeño de cargos en la administración ordinaria. Habría que ahondar más en la constitución de la sociedad local y en cómo esta se reflejaba en los registros eclesiásticos. Un informe de 1755 retrata la decadencia económica de sus habitantes y el temor con que vivían por la cercanía de los indios Motilones. ${ }^{128}$ Al parecer esta ciudad carecía de la dinámica económica y social que habían adquirido las vecinas ciudades de Ocaña y Pamplona, estando ausente la movilidad social entre los sectores prestantes, y dando como resultado la cristalización de una especie de "oligarquía rústica" descendientes de fundadores, encomenderos y propietarios de tierras.

\footnotetext{
126 AGN, SC, CR-CVD, leg.6, ff.376r.-385v., 453r.-466v.

127 AGN, SC, Visitas-Santander, leg.2, ff.989r.-1014v.

128 AGN, SC, Miscelánea, leg.90, ff.554r.-562v.
}

Dossier: Cuestionando las fuentes de archivos: padrones de población, familias y sociedades coloniales en Iberoamérica, ss. XVIII-XIX 
Los censos de otras 25 poblaciones del área de los Andes neogranadinos también registraron las distintas condiciones sociales de sus habitantes. Al igual que en la ciudad de Salazar de las Palmas, en las parroquias de Poyma, San Cayetano, Santiago, en la villa del Socorro se diferenciaba a los "nobles" de los "blancos”, y en los pueblos de indios de Firavitoba, Iza, Chámeza, Monguí, Nobsa y Tibasosa se diferenciaba a los "caballeros" de los "blancos". En algunas se clasificaba a algunos habitantes como "pardos" y a otros como "mulatos". En otras solo se reconocieron "pardos" y en otras solo aparecen "mulatos". Los censos de algunas poblaciones registraron a estas gentes de color aparte de los "negros" y "zambos", mientras que otros los colocaron en un mismo rubro. Los "mestizos" e "indios" aparecen como categorías desglosadas exceptuando a dos poblaciones en las que fueron registrados juntos. Solo en cuatro poblaciones se registraron a los "esclavos" (ver tabla 2).

En los padrones de 9 poblaciones de la provincia de Cartagena solo en 3 se diferenció a "blancos" de "españoles", y en 4 se distinguió a "mulatos" de "pardos". Además, en las poblaciones de Tacaloa los pocos pardos que aparecen eran los que prestaban el servicio miliciano. Para el resto de las gentes, indistintamente de que fueran libres o esclavos, se le registró como mulatos. ${ }^{129}$ Tanto en Tacamocho como en Tacasaluma no aparecen mulatos más si pardos, los que comprendían a libres y esclavos. ${ }^{130}$ En 8 poblaciones de la provincia de Riohacha y en la ciudad de Portobelo no se establecieron esas distinciones (tabla 1).

A diferencia de los casos registrados en las tablas 1 y 2 hubo otros censos que no reconocieron ni las condiciones socio-raciales ni los oficios de los habitantes a pesar de las especificaciones de la orden real de 1776 de anotar "clases, estados y castas". Fue este el caso de padrones de las veinte parroquias y sitios que integraban el Partido de Tierradentro, ${ }^{131}$ y los de las catorce parroquias, sitios y las treinta y cuatro haciendas de trapiches, ganaderas y de labranzas que estaban bajo la ju-

129 AGN, SC, CR-CVD, leg.6, ff.404r.-411v.

130 AGN, SC, Miscelánea, leg.44, ff.959r.-974v.

131 Este partido se correspondía con el área del actual departamento del Atlántico y de algunas poblaciones de la parte norte de la provincia de Cartagena. Comprendía las parroquias de Barranquilla, Sabanalarga, Soledad, Palmar de Candelaria, Santa Catalina, Santo Tomás, Palmar de Varela, Santa Rosa, Sabanagrande, Real de la Cruz, Manatí, Baranoa, Juan de Acosta, Polonuevo, Ponedera y Candelaria, y los pueblos de indios de Galapa, Malambo, Tubará, Piojó y Usiacurí. Los censos pueden consultarse en AGN, SC, Miscelánea, leg.44, ff.975r.-1004v.; AGN, SC, CR-CVD, leg.6, ff.98r.-301v.; leg.8, ff.165r.-211v., 817r.-820v. Un estudio del padrón del Partido de Tierradentro en J. A. Blanco, Obras completas, tomo I, Barranquilla, Universidad del Norte, 2011, pp.227-270.

Dossier: Cuestionando las fuentes de archivos: padrones de población, familias y sociedades coloniales en Iberoamérica, ss. XVIII-XIX 
risdicción de la capitanía aguerra de Mahates, ${ }^{132}$ ambas en la jurisdicción de la provincia de Cartagena.

Con los censos de estos partidos existe una situación particular que llama la atención. Los de Tierradentro los hizo don J uan García Turín, corregidor y justicia mayor de ese partido. Este estaba avecindado en Cartagena de Indias, ciudad a la que había arribado en septiembre de 1774 en calidad de mayordomo del gobernador Juan Pimienta. ${ }^{133}$ En 1776 lo nombraron en el cargo de corregidor, unos pocos meses antes de que realizara el censo, ${ }^{134}$ contando con el aval del virrey Manuel Antonio Flórez quien llegó a Cartagena a comienzos de febrero de ese año, pasando los meses iniciales de su periodo de gobierno en esta ciudad portuaria.

Es posible suponer que García Turín no estuviera familiarizado con los procedimientos que permitían determinar la calidad de los habitantes de ese partido. El desconocimiento de las características sociales de los habitantes de una población era un aspecto que obligaba a tener cuidado por parte de algunos funcionarios. Hasta cierto punto era una situación recurrente pues años después, en 1812, el gobernador de la provincia de Panamá solicitó se le relevara de formar parte de la J unta Preparatoria para levantar el censo de la ciudad homónima para decidir sobre quienes tenían derechos a ser ciudadanos de acuerdo a la recién expedida Constitución de Cádiz, argumentando "El corto tiempo de mi permanencia en esta plaza no me ha dado un pleno conocimiento del verdadero origen del mayor número de los hijos naturales del país [...]”. ${ }^{135}$

También es factible que García Turín haya recibido la orden del virrey Flórez de no detenerse en las particularidades de la población, dado el interés de este en los resúmenes generales. Esto explicaría el hecho de que tampoco se anotara la condición socio-racial en el padrón del partido de Mahates, llevado a cabo por don Santiago de la Torre y León, capitán aguerra, justicia mayor y corregidor, quien era vecino de la población homónima, ${ }^{136}$ y que por tanto debía conocer la calidad social

132 Este partido comprendía las parroquias y sitios de Mahates, Pital, Arjona, San Basilio de Palenque, Timirihuaco, San Etanislao, Rocha, Flamenco, J olojolo, San Benito, Pasacaballos, Ternera y los pueblo de indios de Turbaco y Turbana. También comprendía 20 haciendas trapiches de caña de azúcar, 8 haciendas de ganados y 6 haciendas de labranzas. AGN, SC, CR-CVD, leg.8, ff.760r.-839v. Información sobre el área norte de este partido, colindante con el Canal del Dique, en J . A. Blanco, Obras completas, tomo II, pp.421-550.

133 Sobre el arribo de Juan García Turín a Cartagena ver AGI, Contratación, leg.5519, exp.2, ff.1r.-4v.

134 J. A. Blanco, Obras completas, tomo I, pp.229-230, 250.

135 AGN, Sección Archivos Anexos, fondo I, subfondo 17, leg.14, f.28r.

136 AGN, SC, CR-CVD, leg.8, f.761r.

Dossier: Cuestionando las fuentes de archivos: padrones de población, familias y sociedades coloniales en Iberoamérica, ss. XVIII-XIX 
de sus habitantes. Pero en el cuadro resumen de toda la provincia de Cartagena hecho en 1778 para el gobierno central del virreinato si se registraron los blancos e indios en muchas de las poblaciones de las jurisdicciones del partido de Tierradentro y de la capitanía aguerra de Mahates, lo que lleva a pensar que se habían contabilizado de forma desagregada. La manera como están presentados los informes de 1777 de ambas jurisdicciones (sin ninguna enmendadura) permite concluir que se sacaron en limpio. Y de forma parecida la formación de las milicias disciplinadas de 1780 de las jurisdicciones de Tierradentro, Mahates, Mompox, Lorica y Corozal se hizo ateniéndose a la condición socio-racial de sus integrantes. ${ }^{137}$

Pese a que se ordenó que los padrones siguieran un modelo común (nombres, edades, estados y calidades), los que conocemos de algunas poblaciones neogranadinas contienen tanto variaciones formales en la presentación de los registros de los habitantes, como las particularidades de las sociedades locales y de los puntos de vistas de los empadronadores. Muchos de estos eran personas vecinas de las localidades con conocimientos de sus habitantes, lo que hace pensar que en no pocos casos la determinación de aquellas fue producto de negociaciones entre la lectura del empadronador, la forma como se auto-percibía el empadronado y lo que había consagrado la tradición social local. En la documentación colonial estas formas de conocer aparecen referenciadas como "de vista, trato y comunicación". Francisco Moreno y Escandón, fiscal del virreinato lo expresó en una circular que acompañó la orden real, demandando que se realizara la "[...] descripción de los habitadores de su distrito, sin mover disputa para indagar las clases, y castas de cada uno, sino colocándolos en aquellas en cuya posesión estuviesen" ${ }^{138}$ Ese conocimiento era esencial hasta para la elaboración de los listados de las milicias disciplinadas. En 1779 don Diego Antonio Nieto, maestre de campo y encargado de organizar las milicias en la provincia de Popayán informaba al virrey Manuel Antonio Flórez su actitud al tener que determinar la condición socio-racial de los milicianos: "[...] deseoso yo de no ser instrumento para promover fastidiosas disputas sobre un asunto en el que concurren muchos intereses por estos parajes, y por evitar otros mayores inconvenientes para formar las milicias no he querido hacer por mí los primeros padrones, con la correspondiente distinción de castas. Los he recibido de las justicias en quienes he debido considerar un cabal conocimiento de cada individuo". 139

137 AGN, SC, MM, leg.14, ff.51r.-52v.; 169r.-174v.; 175r.-176v.; 177r.-210v.; leg.15, ff.939r.-940v.; 953r.-955v.; leg.17, ff.204r.-206v.; 260r.-310v.; leg.21, ff.373r.-380v.; leg.48, ff.678r.-680v.

138 AGN, SC, CR-CVD, leg.8, f.225r.

139 AGN, SC, MM, leg.52, f.443r. Diego Antonio Nieto había llegado a Cartagena de Indias en 1762.

Dossier: Cuestionando las fuentes de archivos: padrones de población, familias y sociedades coloniales en Iberoamérica, ss. XVIII-XIX 
En muchos casos los empadronadores procedieron a asignar clasificaciones reputadas a los habitantes de determinados lugares, es decir, tendieron a generalizar para todas las personas lo que se suponía que era la constitución socio-racial de una población. En otras mostraron desconfianza con las autocalificaciones de los habitantes. Por ejemplo, en 1790 el cura del pueblo de Venero, jurisdicción de Tamalameque (provincia de Santa Marta), realizó un padrón de los indios Chimilas y de los vecinos libres ahí avecindados. Al final advirtió: "[...] asimismo van de bulto las clases, pues algunos de ellos mismos la ignoran, y otros quieren ser más de lo que Dios lo ha hecho". 140

Las dudas sobre la calidad de las personas se intentaban resolver haciendo averiguaciones y recibiendo certificaciones de las autoridades y de los sacerdotes. Así se consignó en el padrón de la ciudad de Salazar de las Palmas (jurisdicción de Pamplona) acerca de una situación dudosa: "Nota. Que esta Faviana Pérez, siendo hija de matrimonio trató de negar a su padre por ser mulato, apropiándose por padre a un hombre blanco, porque su madre era mestiza, para que sus hijos corriesen por tales de que dio información, y se dio otra de contrario con 15 testigos, y otros certificados, con lo que quedan en el ser de mulatos, en que Dios los creó". 141

De una familia se dice: "según voz común [pertenece] a la $3^{\text {a }}$ clase". ${ }^{142} \mathrm{O}$ en el caso de un vecino de la parroquia de San Miguel de quien dijo el empadronador que era "[...] hijo de mujer noble, y por su padre corre por mulato y esta calidad no se explica más por no ser su padre de este lugar [...]" ${ }^{143}$ Los tres ejemplos evidencian que en la determinación de la calidad de las personas el conocimiento de la ascendencia familiar era pieza clave, siguiendo en esto un patrón de indagación y determinación muy generalizado, como sucedía con los pleitos judiciales por considerar difamada la honra o menoscabado el estatus social.

Pero las instituciones y los funcionarios también intervenían y podían clasificar a una persona en una situación distinta a la que esta reivindicaba, como tam-

Entre 1764 y 1773 estuvo radicado en Mompox como subteniente y comandante del destacamento militar asignado a ese puerto fluvial. AGN, SC, MM, leg.71, ff.792r.-796v. Luego retornó a Cartagena y en 1778 fue enviado a Popayán a organizar las milicias disciplinadas. En consecuencia, vivió en la provincia de Cartagena tanto la organización de las milicias en 1773, como el levantamiento del censo de 1777. Esto le daba referencias para comparar sociedades en las que las gentes de color eran mayoría y en las que existían distintos sistemas de clasificaciones socio-raciales.

140 AGN, SC, Curas y Obispos, leg.27, f.811r.

141 AGN, SC, CR-CVD, leg.6, f.463v.

142 AGN, SC, CR-CVD, leg.6, f. 466v.

143 AGN, SC, CR-CVD, leg.8, f.538v.

Dossier: Cuestionando las fuentes de archivos: padrones de población, familias y sociedades coloniales en Iberoamérica, ss. XVIII-XIX 
bién mediaban las estrategias de las personas de eludir el pago de los impuestos mediante el cambio de identidad socio-racial, actitud que a su vez estaba asociada a la idea de que los padrones se realizaban para aumentar las cargas fiscales sobre determinados grupos sociales. Quiere esto decir que un factor clave para entender las identidades socio-raciales fue la actitud de las gentes frente a las políticas fiscales de la Corona española y de las autoridades coloniales. Lo que evidencian muchos expedientes de los fondos "Tributos" y "Caciques e indios" como también algunos del fondo "Miscelánea" del Archivo General de la Nación de Colombia son los juegos de las identidades socio-raciales desarrollados por sectores de la población acorde con sus intereses frente al pago de impuestos. Berta Ares-Queija ha sugerido que en el estudio de estos temas se debe tener presente que durante el siglo XVI fue la política fiscal del tributo la que tuvo un efecto diferenciador sobre el discurso oficial y eclesiástico relativo a los distintos grupos. Hasta el momento ambas autoridades empleaban terminologías genéricas para referirse a las distintas mezclas socio-raciales que se estaban produciendo en el Perú hasta la primera mitad de ese siglo. Pero el tributo que pagaban los indios y los intentos por generalizarlos a los demás sectores de la población produjo actitudes diferenciadoras entre los pobladores y en los discursos institucionales. ${ }^{144}$

Donde más se nota esto es en los pleitos entablados por personas que fueron enlistadas como indios para obligarlas a pagar tributos y/ o el impuesto del requinto. Mestizos, mulatos y cuarterones acudieron a las autoridades para que recogieran testimonios de personas que los conocían y para que declarasen cuáles eran sus ascendencias familiares, y cómo eran reputados en las poblaciones que habían nacido o donde vivían. Lo que muestra la lectura de esos expedientes es que las autoridades ordinarias y eclesiásticas tenían dificultades para contar con información detallada sobre las personas, tanto por el mestizaje, por los grados de ilegitimidad de las uniones conyugales y de los nacimientos, como por la movilidad espacial de las personas. Entonces, curas y encomenderos de pueblos de indios, como también los corregidores de naturales clasificaban a gentes no indias entre los obligados a pagar tributos, demoras y estipendios. Esta decisión podía deberse a que seguían las referencias de los ascendientes de los clasificados, población en la que estaban avecindados, rasgos físicos, y por el conocimiento que la comunidad tenía de las

\footnotetext{
144 Berta Ares-Queija, "A los hijos de español y de india, o de indio y española, nos llaman mestizos... Construcciones identitarias en la América colonial española”. Conferencia en el Instituto de Estudos Avancados Transdisciplinares-Universidade Federal de Minas Gerais (sin fecha), p.8; "Las categorías del mestizaje: desafíos a los constreñimientos de un modelo social en el Perú colonial temprano", pp.200-203.
}

Dossier: Cuestionando las fuentes de archivos: padrones de población, familias y sociedades coloniales en Iberoamérica, ss. XVIII-XIX 
personas. Igual sucedía con los indios libres y mulatos y negros libres a los que se les estatuyó el pago del impuesto del requinto.

En consecuencia, quienes se consideraban que por sus condiciones socioraciales estaban por fuera de esas obligaciones protestaban y elevaban representaciones ante las autoridades para que tomasen declaraciones de testigos. Pero al mismo tiempo podía describirle un color que podemos imaginar como una puerta abierta para que potencialmente la identidad se volviera un poco difusa. Así sucedió en 1664 en una matrícula de los indios, negros, mulatos y zambos libres de las poblaciones de la jurisdicción de la ciudad de Vélez que tenían que tributar el requinto. A un indio se le describió como "de nación Coyaima, alto y moreno"; a otro se detalló como "indio que no reconoce encomendero, mediano moreno"; a otro como "indio que no reconoce encomendero, mediano, descolorido"; a otro como "indio criollo"; a otro como "indio acholado criollo". ${ }^{145}$ Sin embargo, en el caso de los indios lo que primaba era tanto la ascendencia familiar como el sitio de residencia, por lo que otras diferencias quedaban opacadas.

En una consulta elevada en 1776 a la Real Audiencia de la provincia de Quito acerca de si los mestizos hijos de indias tenían que tributar el visitador de pueblos de indios temía que declarar lo contrario suscitaría enfrentamientos con los rematadores de tributos pues estos tenía registrados a muchos mestizos como indios. ${ }^{146}$ De igual forma se generaban conflictos entre personas que no tenían ascendencia indígena, pero que por ciertas circunstancias se vieron precisadas a crecer en pueblos de indios, y en consecuencia terminaban matriculadas bajo esta última condición para obligarlas a pagar tributos. Esto sucedió en 1778 cuando un indio del pueblo de Bucaramanga casado con una "mestiza cuarterona", argüía que sus hijos no debían pagar tributo dada la condición de su madre. El indio aludía que su suegra era hija ilegítima de una mestiza y un blanco sin mancha de sangre que había ocupado cargos oficiales importantes en esa zona. Al quedar huérfana a temprana edad la suegra fue criada entre los indios de Bucaramanga y enlistada como india tributaria. El indio que entabló el pleito también mostraba que el consorte de su suegra, padre de su esposa, había sido un alférez de milicias blancas. Concluía que por ser nieta de un blanco e hija de un blanco, y por tener por vía materna abuela mestiza y madre mestiza, "[...] resulta ser mi mujer blanca, y sin mezcla de la tierra, y habiendo yo contraído matrimonio con la dicha [...], mis hijos están en la clase de mestizos, libres de tributar [...]”. Informaba que el cura doctrinero de esa población

145 AGN, SC, Encomiendas, leg.14, ff.930v.-932r.

146 AGN, SC, fondo Tributos, leg.16, ff.566r.-576v.

Dossier: Cuestionando las fuentes de archivos: padrones de población, familias y sociedades coloniales en Iberoamérica, ss. XVIII-XIX 
era renuente a darle los certificados sobre la genealogía de su esposa, amenazándolo con que si los sacaba de la matrícula de los tributarios los retiraba de los servicios que prestaban en la iglesia, "[...] a cuyos oficios los he aplicado, para que en ningún momento les pase perjuicio [...]”. ${ }^{147}$

Con toda seguridad que ambas formas de clasificación estuvieron presentes en los padrones de población de 1777, pues así como había personas que se preocupaban por cómo eran vistas y clasificadas, a otras eso las tenía sin cuidado. La primera situación se evidencia en los casos del interés de muchos por aprovechar la realización de padrones para intentar mejorar de status. El otro caso se condensa en lo que expresó el encargado de levantar el censo de 1791 de la villa de Tepeaca (Nueva España): "Las familias de la gente común por lo regular ponen al arbitrio de quien se lo pregunta las clases a que corresponden y menos preocupados o más humildes que otros que fingen lo que no son, es necesario informarse de lo que fueron sus padres para deducir su calidad y les es indiferente que resulten españoles castizos, mestizo, defendiendo solo el degenerar en pardos o indios tributarios $[\ldots] " .{ }^{148}$

Las lecturas comparadas de los padrones de 1777 de los Andes centrales neogranadinos y de las provincias de Cartagena, Riohacha y Portobelo permiten afirmar que en las primeras, donde la presencia de gente de color era mucho menor en comparación a los blancos, indios y mestizos, las categorías sociales eran muchos más simples. Y sucedía lo contrario en las provincias donde las gentes de color tenían presencia significativa.

En efecto, en los Andes centrales la base del mestizaje estuvo constituida por blancos e indios, mientras que mulatos y pardos se contaban en cantidades menores debido a la baja presencia de esclavos. ${ }^{149}$ Según el resumen del padrón del 1779

\footnotetext{
147 AGN, SC, Tributos, leg.17, ff.777r.bis-798v. Pleitos suscitados porque corregidores de indios clasificaban a mestizos y gentes de otras condiciones como indios en el pueblo de Riosucio para que tributaran pueden verse en AGN, SC, Tributos, leg.17, ff.691r.-772v. Un caso de 1792 en Neiva en AGN, SC, Tributos, leg.16, ff.987r.-1007v. Cácota (Pamplona) en 1701. AGN, SC, Tributos, leg.16, ff.694r.$701 \mathrm{v}$.

148 Archivo General de la Nación (México), Fondo Padrones, vol.38. Citado en J uan C. Garavaglia y J uan C. Grosso, "Identidad, identidades: una visión desde la América hispana -siglos XVIII-XIX”, en Quaderns, n. ${ }^{\circ 25}$, Barcelona, Universidad Autónoma de Barcelona, 2009, p.46.

149 Ver los padrones de negros, mulatos, zambos y zambahigos libres en el pueblo de Guebsa (1693), en la villa de El Socorro (1688), en AGN, SC, CR-CVD, leg.6, ff.393r.-403v. Los de la ciudad de Vélez en 1664 en AGN, SC, Miscelánea, leg.54, ff.124r.-129v., y AGN, SC, Tributos, leg.10, ff.221r.-228v. El listado de Vélez de 1688 en AGN, SC, CR-CVD, leg.6, ff.371r.-383v. Sobre los esclavos y la población de color en la jurisdicción de Girón ver: Yoer Castaño, Esclavos y libertos en la jurisdicción de Girón, 1682-1750, Bucaramanga, tesis de maestría en Historia-Universidad Industrial de Santander, 2007.
}

Dossier: Cuestionando las fuentes de archivos: padrones de población, familias y sociedades coloniales en Iberoamérica, ss. XVIII-XIX 
de la provincia de Tunja solo el 2,3\% de su población era esclava, ${ }^{150}$ cifra que a falta de datos más específicos sobre las gentes de color nos sirve para explicar la baja presencia de libres de color. Algo parecido sucedía en la jurisdicción de Santa Fe de Bogotá en 1780, área en la que los esclavos ascendían al 1,3\% del total de la población, ${ }^{151}$ y según el censo de 1793 de la ciudad homónima esa representatividad solo era del 3,6\%. ${ }^{152}$ Sin embargo, en las jurisdicciones de las ciudades de Girón, Vélezy Pamplona, en las que hubo cultivo de caña de azúcar y minas el empleo de esclavos fue mayor y por tanto la presencia de gente de color fue de alguna significación y las clasificaciones sociales eran más complejas.

En el mundo andino los logros del mestizaje habían sido significativos hasta el punto que en 1806 el Tribunal de Cuentas de la Real Audiencia neogranadina al responder una consulta elevada por el virrey del Nuevo Reino de Granada acerca de si "[...] los hijos naturales habidos de blancos e indias reputados por mestizos" de la jurisdicción de Valledupar (provincia de Santa Marta) tenían que pagar tributo, optó por dejar las decisiones a las costumbres de cada localidad, y agregó que en comparación con zambahigos, mulatos y negros libres, los mestizos

[...] son muy distinguidos y privilegiados [...] De suerte que por razón de su nacimiento siendo de legítimo matrimonio no deben ser excluidos del sacerdocio, ni las mestizas del estado de monjas, o religiosa profesas. Además vemos altamente recomendada su educación en los Colegios Reales destinados para ellos. Pueden traer armas, lo que no es permitido a indios y demás tributarios. Pueden asimismo pasar de una provincia a otra, y avecindarse donde quieran, y aun llevar a España sus mujeres indias, juntamente con los hijos $[\ldots] .153$

En los censos de las ocho poblaciones de la provincia de Riohacha aparecen las categorías de blancos, negros, zambos, indios, mestizos y morenos libres. Estos padrones los adelantaron sacerdotes, alcaldes y comandantes militares de fundaciones recién creadas para contener y al mismo tiempo ir penetrando en los territorios de los indios guajiros. ${ }^{154}$ Alrededor de esas condiciones socio-raciales se habían

En: http://goo.gl/ RqDtTJ .

${ }^{150}$ AGN, SC, CR-CVD, leg.6, ff.261r.-262v.

${ }^{151}$ AGN, Mapas y Planos, Mapoteca 4, ref. 698-A.

152 J oaquín Durán y Díaz, Estado general de todo el virreynato de Santafe de Bogotá en el presente año de 1794, Bogotá, Banco de la República, 2013, p.11.

${ }^{153}$ AGN, SC, Tributos leg.16, f.563v.

${ }^{154}$ AGN, SC, CR-CVD, leg.6, ff.353r., 537v., 553r., 561r., 563v., 570r., 573v., 576r., 581r.

Dossier: Cuestionando las fuentes de archivos: padrones de población, familias y sociedades coloniales en Iberoamérica, ss. XVIII-XIX 
organizado las milicias de blancos, pardos, zambos y morenos libres de Riohacha en $1750^{155}$. J osé Polo Acuña ha mostrado algunos contrastes entre los censos de 1777y el resumen de 1778 de esta provincia, y sobre las informaciones dadas sobre la población indígena no sometida. Así, mientras que en los datos del censo de 1777 que aparece en la tabla 3 se tabularon pocos indios, en el resumen del año siguiente creció de forma significativa la presencia de este grupo en los sitios de Camarones (54,3\% del total de la población), Boronata ( $42 \%$ del total de la población) y aparece la población de Cototama (99\% del total de la población). ${ }^{156}$ Podemos agregar que en ese año se hicieron dos resúmenes: el señalado en el libro del citado historiador, y otro firmado por Antonio Narváez y la Torre que si se atuvo a las indicaciones de las autoridades del virreinato y presentó la información en las columnas de "eclesiásticos, blancos, indios, libres de varios colores y esclavos de varios colores". 157

En esta provincia el mestizaje tuvo unas singularidades evidenciadas por J osé Polo Acuña quien ha destacado que la sociedad de los indios Wayuú era matrifocal, y en consecuencia podían absorber a otros grupos socio-raciales, como sucedía con muchos de los mestizos que aparecen registrados en los censos de esa área.158 También muestra que esos censos no registraron a una inmensa mayoría de la población de indios, la que vivía fuera del control de las autoridades coloniales, y la que solo pudo ser calculada debido a que permanecía en continuas guerras con los asentamientos españoles.

\section{Censos posteriores a 1777}

Los censos posteriores al de 1777 contienen muchas ambivalencias en las formas de registrar la condición social de la población. Por ejemplo, los padrones de 1778 de Girón, ${ }^{159}$ Piedecuesta, ${ }^{160}$ San Roque y Puerto de Botija ${ }^{161}$ en jurisdicción de la pro-

\footnotetext{
155 AGN, SC, Visitas-Magdalena, leg.1, ff.868r.-879v.

${ }^{156} \mathrm{~J}$. Polo, Indígenas, poderes y mediaciones en la Guajira, pp.49-60.

${ }^{157}$ AGN, SC, CR-CVD, leg.6, f.360r.

$158 \mathrm{~J}$. Polo, Indígenas, poderes y mediaciones en la Guajira, pp.231-271. Sobre el resumen del censo de la provincia de Riohacha en 1778 ver: AGN, SC, CR-CVD, leg.6, f.360r.

159 AGN, SC, CR-CVD, leg.8, ff.879r.-885v.

160 AGN, SC, CR-CVD, leg.6, ff.404r.-411v.

161 AGN, SC, CR-CVD, leg.8, ff.666r.-668v.
}

Dossier: Cuestionando las fuentes de archivos: padrones de población, familias y sociedades coloniales en Iberoamérica, ss. XVIII-XIX 
vincia de Girón, solo señalaron a los cabezas de familias y sus calidades ("blancos", "gentes de varios colores", "indios" y "eclesiásticos"). Los padrones de 1788 de las poblaciones de Rio Viejo, Regidor y San Pedro, al sur de la provincia de Cartagena, si registraron a gentes de "color blanco", "pardos libres", "color indio", "color mestiza”, "indios" y "esclavos". 162 Y el 1791 del pueblo de Venero (jurisdicción de Tamalameque, provincia de Santa Marta) especificó a los "indios chimilas", "blancos", "negros", "mestizos" y "zambos". 163 Las poblaciones de Caloto y Quilichao (provincia de Popayán), enfrascadas en un fuerte conflicto de jurisdicciones, fueron empadronadas en 1791. El de Caloto registró una mayoría de mestizos, seguidos por los esclavos, mulatos, blancos, nobles, negros libres e indios. ${ }^{164} \mathrm{~A}$ las anteriores categorías socio-raciales el de Quilichao agregó las de pardos, negros esclavos y mulatos esclavos. ${ }^{165}$

El padrón de Cali de 1797 clasificó a la población en nobles, blancos, mestizos, indios, mulatos, negros, pardos. 166 En 1801 se realizó un empadronamiento de la población de Santa Fe de Bogotá para llevar un registro de las personas contagiadas y de las que se salvaron de la epidemia de viruela, y en algunos padrones de sus barrios se clasificaron a los habitantes en "nobles", "blancos", "indios, "mestizos", "mulatos" y "negros". 167 El censo de Popayán de 1807 solo empleó las categorías de nobles, mestizos, mulatos libres, indios, negros libres y esclavos negros, pardos y mulatos. 168

En los censos e informes sobre habitantes de poblaciones que aspiraban a desglosarse de las jurisdicciones de otras ciudades o villas y alcanzar alguna de esas categorías, la presentación de las calidades de las personas podía o no presentarse o ser modificadas. Esto se debía a que actuaban bajo la condición política de vecinos que procuraban un propósito común, y l interés en mostrar que se contaba con hombres de buenas calidades y competentes para los cargos de la administración local. Esto era muy usual en los casos en que hombres libres de distintas condiciones vivían en los términos de un pueblo de indios y solicitaban que por disminu-

\footnotetext{
162 AGN, SC, CR-CVD, leg.6, ff.427r.-430r.

163 AGN, SC, Curas y Obispos, leg.27, ff.810r.-811r.

164 AGN, SC, Poblaciones, leg.2, ff.700r.-706v.

165 AGN, SC, Poblaciones, leg.2, ff.709r.-720r.

166 Archivo Histórico de Cali, Libro Capitular de 1797, ff.1r.-110v.

167 AGN, SC, Miscelánea, leg.22, ff.266r.-389v.

168 Sociedad Genealógica de Utah, microfilme n. ${ }^{\circ} 1389116$. Agradezco al colega Luis Erwin Prado, profesor de la Universidad del Cauca, la gentileza de cederme una copia digitalizada de este censo.
}

Dossier: Cuestionando las fuentes de archivos: padrones de población, familias y sociedades coloniales en Iberoamérica, ss. XVIII-XIX 
ción de estos o por su traslado, el pueblo se transformara en parroquia de vecinos libres. Véase, a manera de ilustración, el caso del traslado de los indios de Pereira (provincia de Antioquia) a otro lugar en 1783, y el listado de los vecinos libres solicitando la erección del pueblo en parroquia.169 También fue el caso de la información levantada en 1778 con el fin de que la parroquia de Marinilla (provincia de Antioquia) fuera erigida en villa, ${ }^{170}$ y el caso del censo de Cúcuta de 1792, levantado para que la parroquia (otrora pueblo de indios) también se erigiera en villa, en el que no se registró la condición socio-racial de los habitantes. ${ }^{171}$ El resumen del censo de la población de la jurisdicción de Llano Grande (Buga, Cali y Caloto, provincia de Popayán) fue presentado a las autoridades del virreinato en 1794 por los patricios de esa población con el fin de alcanzar el status político-administrativo de villa. El énfasis de este resumen estuvo en cruzar las variables socio-raciales (blancos, mestizos, mulatos, negros, esclavos e indios) con la riqueza, para mostrar que se contaba con los recursos para sostener el tren administrativo que demandaba el rango político que solicitaban. ${ }^{172}$ Como ya hemos mostrados unas pocas líneas más arriba, dos años antes, en el censo del sitio de Quilichao, jurisdicción de Caloto, aparecían nobles, blancos, negros libres, esclavos, mestizos, mulatos, pardos e indios. En el de Caloto del mismo año los únicos que no aparecían eran los pardos, lo que significa que en la representación de 1794 estos fueron disueltos en la categoría de mulatos. ${ }^{173}$

Lo cierto es que en la información de los archivos se nota dos hechos que debemos resaltar. Por una parte continuó siendo ambivalente pues mientras que en muchos documentos los funcionarios oficiales omitieron registrar esa condición, en otros si se continuó haciendo. Y por otro lado también se observa una tendencia en la documentación oficial a reducir la diversidad de categorías socio-raciales a las de blancos, indios, negros, mestizos y mulatos (o en defecto de esta, pardo). Por ejemplo, en 1804 el párroco de la parroquia de Santa Ana, jurisdicción de Tamalameque (provincia de Santa Marta), en informe rendido para el Rey afirmó que la mayoría de la población estaba constituida por "negros y zambos, cuyas costumbres relajadas y perversas inclinaciones no dan lugar al fomento ni esperanza a progreso alguno. Antes por el contrario, como enemigos del buen gobierno se oponen a que

\footnotetext{
169 AGN, SC, Fondo Caciques e Indios, leg.46, ff.1r.-32v.

170 AGN, SC, Poblaciones, leg.10, ff.545r.-645v.

171 AGN, SC, CR-CVD, leg.8, ff.319r.-347r.

172 AGN, SC, CR-CVD, leg.6, f.477r.

173 AGN, SC, Poblaciones, leg.2, ff.701r.-706v., y 709r.-920r.
}

Dossier: Cuestionando las fuentes de archivos: padrones de población, familias y sociedades coloniales en Iberoamérica, ss. XVIII-XIX 
haya blancos que puedan emprenderlo". Y un poco más adelante describía a la población de Santa Ana como una mayoría de "mestizos y zambos de indios". ${ }^{174}$

Un caso que llama la atención es el de los censos de 1784 de las poblaciones de Sahagún, Chinú, Corozal, Sincelejo, Sincé, Caimito y San Benito Abad (situadas en las sabanas del área central de la provincia de Cartagena) solo contienen información de los vecinos cabezas de familias, sus consortes y las cifras de los hijos. No especificaron edades, ni ocupaciones, ni calidades. Algunos se organizaron en orden alfabético según los nombres de las personas, lo que no permite acceder a información sobre las características de la unidad familiar. Otros están organizados por estados civiles (casados, viudos y solteros). Y otros procedieron a registrar a las cabezas de familias, sus esposas y el número total de hijos. ${ }^{175}$ Los de Corozal y Chinú fueron copiados de los respectivos padrones eclesiásticos. ${ }^{176}$ Lo mismo sucedió con las poblaciones de la jurisdicción del partido de Lorica, situadas entre el bajo curso del rio Sinú y el del rio San J orge. ${ }^{177}$

Se trató de unos censos hechos con mucha premura. Las razones las explicó don Antonio de la Torre y Miranda, comisionado por el virrey y el gobernador de la provincia de Cartagena para que adelantara el censo en las jurisdicciones de Lorica, Tolú, Montes de María y el San Benito Abad, en carta de 10 de septiembre que dirigió a las autoridades de esas poblaciones:

Oficios remitidos a varios J ueces. Muy señor mío: Habiéndome comisionado el Excelentísimo Señor Virrey, y Señores de la J unta de Tribunales en asuntos interesantes al Real servicio como verá Vuestra Merced por la adjunta carta orden de este señor Gobernador, y siendo su objeto el que se me franqueen todos los auxilios que pida de cualesquiera naturaleza que sean, y necesitando un pleno conocimiento de las familias que habitan en cada uno de esos vecindarios, me precisa pedir a Vuestra Merced un padrón individual que contenga todos sus vecinos y habitadores, bien entendido que por la prontitud que exige, bastará solo poner el nombre de la cabeza de familia, añadiendo a él su mujer, viudo o soltero, y tantos hijos en guarismos, como también poner por separado aquellos sujetos de costumbres estragadas, viciosos o perjudiciales en las poblaciones. Advirtiendo a Vuestra Merced me hallo con las facultades suficientes para castigar por mi cualquier falta de legalidad, omisión o demora. Dicho padrón debe estar en mi poder a fines de este mes, y de

\footnotetext{
174 AGN, SC, Curas y Obispos, leg.10, ff.423r.-v.

175 AGN, SC, MM, leg.141, ff.365r.-433v.

176 AGN, SC, MM, leg.141, f.375v.

177 AGN, SC, MM, leg.141, ff.42r.-139v.
}

Dossier: Cuestionando las fuentes de archivos: padrones de población, familias y sociedades coloniales en Iberoamérica, ss. XVIII-XIX 
lo contrario será Vuestra Merced responsable al Excelentísimo Señor Virrey $[\ldots] .178$

\section{Conclusiones}

Por lo regular las interpretaciones de la sociedad neogranadina de la segunda mitad del siglo XVIII afrontan dos problemas de orden metodológico. Uno es la influencia de algunos modelos académicos estadounidenses que piensan la configuración social latinoamericana en los términos en que se mira la sociedad norteamericana, desapareciendo el amplio espectro de diferenciación entre las gentes de color que tenía sus implicaciones sociales. El otro problema se refiere a que el empleo del resumen del censo de 1777 con sus columnas de blancos, indios, libres de todos los colores y esclavos de varios colores, ha originado una lectura reduccionista de la sociedad neogranadina. Los historiadores que estudian ese periodo poco reflexionan sobre las fuentes de archivos que emplean en la construcción de sus discursos. Interesados en subrayar los desajustes que introdujo el mestizaje en la organización inicial de la sociedad colonial en las repúblicas de blancos y de indios y en la movilidad social que produjo, ${ }^{179}$ dejan de lado el hecho de que el mestizaje también reconfiguró las jerarquías sociales basadas en la intensidad del blanqueamiento y en los estilos de vida que se reflejaban en la calificación de la calidad de las personas. Redefinió en muchos lugares la condición de blanco, originando diferenciaciones con relación a los sectores más bajos en concordancia con la claridad que iba tomando el color de piel.

El nudo gordiano a desatar por los estudios es el que se forma por el cruce de las taxonomías sociales que se expresaban en las categorías desagregadas que aparecen en los padrones de las localidades y en otras informaciones de archivos, con la tendencia institucional a la simplificación de las representaciones de los segmentos se la sociedad, las transformaciones que se fueron operando en la esfera de la participación política gracias a la triple condición de vasallos, vecinos y milicianos, y las presiones de sectores subordinados en pro de una redistribución de algunas simbologías y rituales de la prestancia social. Las gentes ponían en escena distintas

178 AGN, SC, MM, leg.141, f.97r.; AGN, SC, fondo Visitas-Bolívar, leg.10, ff.1007r.-1030v.Este personaje conocía con detalle las características de las poblaciones de esa área. Pilar Moreno, Antonio de la Torre y Miranda. Viajero y poblador, Bogotá, Planeta, 1993, pp.63-169.

179 Jaime Jaramillo, "Mestizaje y diferenciación social en el Nuevo Reino de Granada en la segunda mitad del siglo XVIII", en Anuario Colombiano de Historia Social y de la Cultura, n. ${ }^{\circ}$, Bogotá, Universidad Nacional, 1965, pp.21-48.

Dossier: Cuestionando las fuentes de archivos: padrones de población, familias y sociedades coloniales en Iberoamérica, ss. XVIII-XIX 
identidades acorde con los espacios en que se movían. La mujer que en 1797 denuncia al hombre en Mompox por incumplimiento de promesa matrimonial alegó varias condiciones: "vecina", pues le permitía acudir a la justicia para reclamar derechos. "Parda" pues le permitía demostrar que estaba en condición de igualdad al demandado. $Y$ "honesta" porque le permitía reclamar un derecho que el conjunto de la comunidad le reconocía. ${ }^{180}$ Cuando una comunidad acudía a las autoridades en reclamo de un derecho hacía uso de la condición de vecinos. Pero cuando se trataba de pleitos personales la condición "racial" y la posición en la jerarquía social salían a relucir.

No cabe la menor duda que distintos factores habían contribuido a darle flexibilidad a las fronteras entre algunas categorías sociales que podían hallarse próximas, incidiendo en las simplificaciones institucionales. La indumentaria, el uso del "don" y "doña", ${ }^{181}$ y las disputas planteadas por los pardos al interior de las milicias en torno a ciertos aspectos simbólicos de reconocimiento social y militar, constituyeron expresiones de un movimiento real en la sociedad tendiente a reacomodar los criterios de la jerarquía y prestancia social. Sin embargo, esa tendencia no significa que hayan desaparecido de manera automática las diferencias sociales basadas en las calidades de las personas. Estudios para otras latitudes han mostrado que los cambios encontraron resistencias entre diversos sectores, los que se vieron precisados a reelaborar los criterios de exclusión y de prestancia social. Aunque por normatividad propia de la democracia liberal desapareció de la documentación oficial cualquier referencia a la condición racial de las personas, en las afiliaciones de quienes eran buscados por la justicia aparecían unas descripciones que remiten al imaginario social del siglo XVIII. En un listado que contiene a 270 desertores del ejército y reos prófugos de Cartagena correspondiente a los años de 1845-1848 se les identificaba por el color de la piel como "zambo", "pardo", "mulato", "blanco", "mestizo", "indígena”, "moreno claro", "claro", "castaño", "prieto", "achinado", "oscuro", "trigueño" y "negro" ${ }^{182}$ Y no era solo un aspecto de la Colombia de entonces, pues el censo de Lima de 1860 también registró la condición socio-racial de la población en blancos, indios, negros, mestizos, natural, mula-

180 AGN, SC, Miscelánea, t.82, f.280r.

181 En 1759 se reconocía que en la ciudad de Cartagena de Indias la indumentaria estaba dejando de ser un elemento de diferenciación social entre blancas y mulatas. AGN, SC, fondo Genealogías, leg.1, ff.304r., 308v. En 1798 se señalaba que en la ciudad de Simití con el distintivo de "don", no se reconoce "[...] con él a ninguna clase de persona, que tanto se lo dan al noble como al mulato y demás inferiores". AGN, SC, Fondo J uicios Criminales, leg.80, ff.304r.-305v., 307v.

182 J orge Conde, Buscando la nación. Ciudadanía, clase y tensión racial en el Caribe colombiano, 1821-1855, Medellín, Universidad del Atlántico/ La Carreta Editores, 2009, pp.343-351.

Dossier: Cuestionando las fuentes de archivos: padrones de población, familias y sociedades coloniales en Iberoamérica, ss. XVIII-XIX 
tos, cholos, pardos, chinos (de origen afroperuano), prietos y chinos (de origen asiático). ${ }^{183}$

\section{Bibliografía}

\section{Fuentes primarias:}

Archivo General de Indias (España) (AGI), Estado, Contratación, Lima, Santa Fe; Sección Mapas y Planos-Varios.

Archivo General de Simancas (España), Secretaría de Despacho de Guerra (AGS, SDG); Dirección General de Rentas.

Archivo General de la Nación (Colombia), Sección Colonia (AGN, SC), fondos: Caciques e Indios; Censos Redimibles-Censos Varios Departamentos (CR-CVD); Censos Varios; Curas y Obispos; Encomiendas; Fábrica de Iglesias; Genealogías; Historia Civil; Juicios Criminales; Milicias y Marina (MM); Miscelánea; Poblaciones; Poblaciones-Varias; Policía; Residencias-Bolívar; Virreyes; Visitas-Bolívar; Visitas-Magdalena; VisitasSantander; Tributos. Sección Archivos Anexos; Sección Colecciones, Enrique Ortega Ricaurte(SCs., EOR); Sección Mapas y Planos.

Archivo General de la Nación (México), fondo Padrones.

Archivo Histórico de Antioquia (Colombia), fondos: Capitulares de Antioquia; Estadística y Censo; Reales Cédulas.

Archivo Histórico de Cali (Colombia), Libro Capitular de 1797.

Archivo Histórico de Veracruz (México), Padrón de la ciudad de Veracruz, 1791.

Archivo Histórico Nacional de Madrid (España), Consejos; Diversos-Colecciones.

Biblioteca Digital Hispánica de la Biblioteca Nacional de España, Numeración general de todas las personas de ambos sexos, edades y calidades que se ha hecho en esta ciudad de Lima, año de 170o, 2 tomos, 360 folios. http://bdhrd.bne.es/viewer.vm?id=0000042087\&page=1. (Consulta: mayo 2 de 2013).

Sociedad Genealógica de Utah (Estados Unidos), microfilme n. ${ }^{\circledR} 1389116$.

\section{Fuentes primarias impresas:}

Carbonari, María Rosa (ed.), El censo de 1778. El partido de Rio Cuatro, Ciudad de Rio Cuatro, Universidad Nacional de Rio Cuatro, 2003.

Castro, Hugo, México en 1790 (el censo condenado), México D. F., Sociedad Mexicana de Geografía y Estadística/Instituto Nacional de Estadística, Geografía e Informática/ Instituto Nacional de Geografía y Estadística, 1988.

183 J esús Cosamalón, Babel en los Andes. Población y mestizaje en Lima (186o), México, Tesis para optar al título de doctor en Historia en El Colegio de México, 2009, pp.134-143.

Dossier: Cuestionando las fuentes de archivos: padrones de población, familias y sociedades coloniales en Iberoamérica, ss. XVIII-XIX 
Censo de Aranda, tomo I, Madrid, Real Academia de la Historia/ Instituto Nacional de Estadística, $1991 . \quad$ (Edición facsimilar). http://www.ine.es/prodyser/pubweb/censo_aranda/tomo1.pdf (Consulta: abril 2 de 2013).

Censo español executado de Orden del Rey, comunicada por el Excelentísimo Señor Conde de Floridablanca, Primer Secretario del Estado y del Despacho, en el año de 1787, Madrid, Imprenta $\quad$ Real, 1787. http://bibliotecadigital.jcyl.es/i18n/_catalogo_imagenes/grupo.cmd?path=10074515 (Consulta: abril 4 de 2013).

Colmenares, Germán (ed.), Relaciones e informes de los gobernantes de la Nueva Granada, tomo I, Bogotá, Banco Popular, 1989.

Durán y Díaz, J oaquín, Estado general de todo el virreynato de Santafe de Bogotá en el presente año de 1794, Bogotá, Banco de la República, 2013.

Martí, Mariano, Documentos relativos a su visita pastoral de la Diócesis de Caracas, tomo VII, Caracas, Biblioteca de la Academia Nacional de la Historia 1998.

Mier, J osé de (comp.), Poblamientos en la Provincia de Santa Marta. Siglo XVIII, tomo I, Bogotá, Colegio Máximo de la Academia de Colombia/Libreros Colombianos, 1987.

Moreau de Saint-Méry, M. L. E., Description topographique, physique, civile, politique et historique de la partie française de l'isle Saint-Domingue, tome premier, Paris, T. Morgand/L. 1797. https:// ia700300.us.archive.org/29/items/ descriptiontopog00more/ descriptiontopog00more.pdf

Peredo, Diego de, "Noticia historial de la provincia de Cartagena de las Indias año 1772", en Anuario Colombiano de Historia Social y de la Cultura n. ${ }^{\circ} 6-7$, Bogotá, Universidad Nacional, 1972, pp.118-154.

Ponce, Pilar (ed.), Relaciones histórico-geográficas de la Audiencia de Quito. Siglos XVIXIX, 2 tomos, Madrid, Consejo Superior de Investigaciones Científicas, 1991.

Solano, Francisco de (ed.), Cuestionarios para la formación de las relaciones geográficas de Indias. Siglos XVI-XIX, Madrid, Consejo Superior de Investigaciones Científicas, 1988.

Solórzano y Pereyra, Juan de, Política indiana, vol.1, Madrid, Matheo Sacristán, 1736. http:// books.google.es/books?id=huEykw_YtzYC\&printsec=frontcover\&hl=es\&source=gbs_ge_summary_r\&cad=0\#v= onepage\&q\&f=false. (Consulta: abril 6 de 2013).

Tovar, Hermes, Tovar, Camilo y Tovar, J orge, Convocatoria al poder del número. Censos y estadísticas de la Nueva Granada (1750-1830), Bogotá, Archivo General de la Nación, 1995.

Vega, Garcilaso de la, Comentarios reales, tomo II, Caracas, Biblioteca Ayacucho, 1976.

\section{Fuentes secundarias:}

Aguilera, María y Meisel, Adolfo, Tres siglos de historia demográfica de Cartagena de Indias, Cartagena, Banco de la República, 2009.

Araya, Alejandra, "Registrar a la plebe o el color de las castas: 'calidad', 'clase' y 'casta' en la Matrícula de Alday (Chile, siglo XVIII)”, en Alejandra Araya y Jaime Valenzuela (eds.),

Dossier: Cuestionando las fuentes de archivos: padrones de población, familias y sociedades coloniales en Iberoamérica, ss. XVIII-XIX 
América colonial. Denominaciones, clasificaciones e identidades, Santiago de Chile, Pontificia Universidad Católica de Chile/ Universidad de Chile/Red Internacional del Libro, 2010, pp.331-362.

Araya, Alejandra, "La Matrícula de Alday (1777-1778): imaginarios sociales y políticos en el siglo XVIII americano", en Grupo de Estudio de Historia de las Ciencias (eds.), Control social y objetivación: escrituras y tránsitos de las Ciencias en Chile, Santiago de Chile, Universidad de Chile, 2012, pp.15-33.

Ares-Queija, Berta, "Mestizos, mulatos y zambaigos (virreinato del Perú siglo XVI)", en Berta Ares-Queija y Alessandro Stella (coords.), Negros, mulatos, zambaigos. Derroteros africanos en los mundos ibéricos, París/Sevilla, Centre National de la Recherche Scientifique/ Escuela de Estudios Hispano Americanos, 2000, pp.75-88.

Ares-Queija, Berta, "Las categorías del mestizaje: desafíos a los constreñimientos de un modelo social en el Perú colonial temprano", en Histórica vol.XVIII, n. ${ }^{\circ} 1$, Lima, Pontificia Universidad Católica de Perú, 2004, pp.204-205.

Ares-Queija, Berta, "A los hijos de español y de india, o de indio y española, nos llaman mestizos... Construcciones identitarias en la América colonial española”. Conferencia en el Instituto de Estudos Avancados Transdisciplinares-Universidade Federal de Minas Gerais ( $\sin$ fecha).

Blanco, J osé A., Obras completas, tomos I y II, Barranquilla, Universidad del Norte, 20112014.

Borchart, Cristina, El corregimiento de Otavalo: Territorio, población y producción textil (1535-1808), Quito, Universidad de Otavalo, 2007.

Brading, David, "Grupos étnicos, clases y estructura ocupacional en Guanajuato colonial (1792)”, en Historia Mexicana vol.21, n. ${ }^{\circ 3}$, México D. F., El Colegio de México, 1972, pp.461-462.

Carbonari, María Rosa, População, fronteira e família. A região de Río Cuarto no período colonial tardio, Niterói, tesis doctoral-Universidade Federal Fluminense, 2001. http:// www.livrosgratis.com.br/arquivos_livros/cp000199.pdf. (Consulta: junio 7 de 2013).

Castaño, Yoer, Esclavos y libertos en la jurisdicción de Girón, 1682-175o, Bucaramanga, tesis de maestría en Historia-Universidad Industrial de Santander, 2007.

Castro Aranda, Hugo, Primer censo de Nueva España. Censo de Revillagigedo "un censo condenado", México D. F., Sociedad Mexicana de Geografía y Estadística/Instituto Nacional de Geografía y Estadística, 2010.

Castro Morales, Efraín, "Los cuadros de castas de la Nueva España", en Jahrbuch für Geschichte von Staat, Wirtschaft, Besellschaft Lateinamerikas n. ${ }^{\circ 20}$, Viena, Universität Graz, 1983, pp.1-15.

Conde, J orge, Buscando la nación. Ciudadanía, clase y tensión racial en el Caribe colombiano, 1821-1855, Medellín, Universidad del Atlántico/ La Carreta Eds., 2009.

Cosamalón, J esús, Babel en los Andes. Población y mestizaje en Lima (1860), México D. F., Tesis para optar al título de doctor en Historia en El Colegio de México, 2009.

Dossier: Cuestionando las fuentes de archivos: padrones de población, familias y sociedades coloniales en Iberoamérica, ss. XVIII-XIX 
Chaves, María E., "La creación del ‘otro’ colonial. Apuntes para un estudio de la diferencia en el proceso de la conquista americana y de la esclavización de los africanos", en María E. Chaves (ed.), Genealogías de la diferencia. Tecnologías de la salvación y representación de los africanos esclavizados en Iberoamérica colonial, Bogotá, Universidad J averiana, 2009, pp.178-243.

Fernández, Manuel, España y los españoles en los tiempos modernos, Salamanca, Universidad de Salamanca, 1979.

Fra Molinero, Baltasar, "Ser mulato en España y América: discursos legales y otros discursos literararios”, en Berta Ares-Queija y Alessandro Stella (coords.), Negros, mulatos, zambaigos. Derroteros africanos en los mundos ibéricos, París/Sevilla, Centre National de la Recherche Scientifique/ Escuela de Estudios Hispano Americanos, 2000, pp.123-147.

Garavaglia, Juan C. y Grosso, J uan C., "Identidad, identidades: una visión desde la América hispana - siglos XVIII-XIX", en Quaderns n. ${ }^{\circ 25}$, Barcelona, Universidad Autónoma de Barcelona, 2009, pp.19-45.

García, Eduardo, “Censos de población españoles”, en Estadística Española n. ${ }^{\circ} 128$, Madrid, Instituto Nacional de Estadística, 1991, pp.441-500.

Gutiérrez, Ildefonso, "Los libros de registro de pardos y morenos en los archivos parroquiales de Cartagena de Indias", en Revista Española de Antropología Americana n. ${ }^{\circ}$ XIII, Madrid, Universidad Complutense, 1983, pp.121-141.

Hernández, J uan, "La realización del censo de Floridablanca en el corregimiento de Murcia”, en Studia Histórica: Historia Moderna n. ${ }^{\circ}$, Salamanca, Universidad de Salamanca, 1987, pp.285-297.

Herrera, Marta, Ordenar para controlar. Ordenamiento espacial y control político en las llanuras del Caribe y en los Andes centrales neogranadinos, siglo XVIII, Bogotá, Instituto Colombiano de Antropología e Historia/ Academia Colombiana de Historia, 2002.

Herrera, Marta, "libres de todos los colores el ordenamiento social en las llanuras del Caribe, siglo XVIII", en Alberto Abello (comp.), El Caribe en la nación colombiana. (Memorias), Bogotá, Museo Nacional de Colombia/Observatorio del Caribe Colombiano, 2006, pp.248-268.

J aramillo Uribe, J aime, "Mestizaje y diferenciación social en el Nuevo Reino de Granada en la segunda mitad del siglo XVII", en Anuario Colombiano de Historia Social y de la Cultura n. ${ }^{\circ}$ 3, Bogotá, Universidad Nacional, 1965, pp.21-48.

Marchena, Juan, “Su Majestad quiere saber' Información oficial y reformismo borbónico: el mundo andino bajo la mirada de la "Ilustración”, en Procesos n. ${ }^{\circ} 22$, Quito, Universidad Andina Simón Bolívar, 2005, pp.45-83.

Meisel, Adolfo y Aguilera, María, Tres siglos de historia demográfica de Cartagena de Indias, Cartagena, Banco de la República, 2009.

Miño, Manuel, "Para la historia social. Tablas de edad, estado marital y grupos raciales de la población de la Ciudad de México, 1790 (13 cuarteles)", en Historia Mexicana vol.LVII, n. ${ }^{\circ 3}$, México D. F., El Colegio de México, 2008, pp.911-944.

Moreno, Pilar, Antonio de la Torre y Miranda. Viajero y poblador, Bogotá, Planeta, 1993.

Dossier: Cuestionando las fuentes de archivos: padrones de población, familias y sociedades coloniales en Iberoamérica, ss. XVIII-XIX 
Mörner, Magnus, La mezcla de razas en la historia de América Latina, Buenos Aires, Paidós, 1969.

Pérez, Ana M. y Montoya, J uan, "La invención de la población: salud y riqueza en el Nuevo Reino de Granada, 1760-1810”, en Secuencia n. ${ }^{\circ 78}$, México D. F., Instituto Mora, 2010, pp.17-42.

Pérez Moreda, Vicente, "La estadística demográfica en el gobierno de la España ilustrada: recuerdo y elogio del Censo de Floridablanca", en Índice n. ${ }^{\circ} 43$, Madrid, Instituto Nacional de Estadística/Universidad Autónoma de Madrid, 2010, pp.8-17.

Polo Acuña, José, Indígenas, poderes y mediaciones en la Guajira en la transición de la Colonia a la República (1750-1850), Bogotá, Universidad de los Andes, 2012.

Ruiz, J ulián, Fuentes para la demografía histórica de Nueva Granada, Sevilla, Escuela de Estudios Hispano Americanos, 1972.

Ruiz, Julián, Los indios de Cartagena bajo la administración española en el siglo XVII, Bogotá, Archivo General de la Nación, 1996.

Saether, Steinar, Identidades e Independencia en Santa Marta y Riohacha, 1750-1850, Bogotá, Instituto Colombiano de Antropología e Historia, 2005.

Sánchez, Ernest, Padrón del arzobispado de México 1777, México D. F., Archivo General de la Nación, 2003.

Solano, Sergio Paolo, "Raza, trabajo, liberalismo y honorabilidad en Colombia durante el siglo XIX", en Sergio Paolo Solano y Roicer Flórez, Infancia de la Nación. Colombia en el primer siglo de la República, Cartagena, Eds. Pluma de Mompox, 2011, pp.23-68.

Solano, Sergio Paolo, "Padrones de población e historiografía sobre la configuración socioracial hispanoamericana del siglo XVIII", en El Taller de la Historia vol.5, n. ${ }^{\circ}$, Cartagena, Universidad de Cartagena, 2013, pp.125-172. 